\title{
Amazon River dissolved load: temporal dynamics and annual budget from the Andes to the ocean
}

\author{
Jean-Sébastien Moquet ${ }^{1} \cdot$ Jean-Loup Guyot $^{1,2}$ - Alain Crave $^{3}$ - Jérôme Viers ${ }^{1}$. \\ Naziano Filizola ${ }^{4}$. Jean-Michel Martinez ${ }^{1}$. Tereza Cristina Oliveira ${ }^{4}$. \\ Liz Stefanny Hidalgo Sánchez ${ }^{5,6}$ • Christelle Lagane ${ }^{1}$ • Waldo Sven Lavado Casimiro ${ }^{6}$. \\ Luis Noriega $^{7} \cdot$ Rodrigo Pombosa ${ }^{8}$
}

Received: 31 March 2015 / Accepted: 23 September 2015

(C) Springer-Verlag Berlin Heidelberg 2015

\begin{abstract}
The aim of the present study is to estimate the export fluxes of major dissolved species at the scale of the Amazon basin, to identify the main parameters controlling their spatial distribution and to identify the role of discharge variability in the variability of the total dissolved solid (TDS) flux through the hydrological cycle. Data are compiled from the monthly hydrochemistry and daily discharge database of the "Programa Climatologico y Hidrologico de la Cuenca Amazonica de Bolivia" (PHICAB) and the HYBAM observatories from 34 stations distributed over the Amazon basin (for the 1983-1992 and 2000-2012 periods, respectively).
\end{abstract}

\section{Responsible editor: Philippe Garrigues}

Electronic supplementary material The online version of this article (doi:10.1007/s11356-015-5503-6) contains supplementary material, which is available to authorized users.

Jean-Sébastien Moquet

jean-sebastien.moquet@ird.fr

1 Geosciences Environnement Toulouse / Observatoire Midi-Pyrénées, CNRS/IRD/Université Paul Sabatier, 14 avenue Edouard Belin, 31400 Toulouse, France

2 IRD, Casilla, 18-1209, Lima 18, Peru

3 Géosciences Rennes (UMR CNRS 6118)/OSUR, Université de Rennes 1, Bâtiment 1, Campus de Beaulieu, CS 74205, 35042 Rennes Cedex, France

4 LAPA (Laboratório de Potamologia da Amazônia), Universidade Federal do Amazonas, Av. General Rodrigo Octávio Jordão Ramos, 3000, Campus Universitário, Bloco Arthur Reis, Coroado, Manaus, Brazil

5 Universidade Federal do Amazonas, Manaus, Brazil

6 SENAMHI, Casilla 11, 1308, Lima 11, Peru

7 SENAMHI, Calle Reyes Ortiz no. 41 2do Piso, La Paz, Bolivia

8 INAMHI, Iñaquito N36-14 y Corea, Código 16-310 Quito, Ecuador
This paper consists of a first global observation of the fluxes and temporal dynamics of each geomorphological domain of the Amazon basin. Based on mean interannual monthly flux calculations, we estimated that the Amazon basin delivered approximately $272 \times 10^{6} \mathrm{t}$ year $^{-1}$ (263-278) of TDS during the 2003-2012 period, which represents approximately $7 \%$ of the continental inputs to the oceans. This flux is mainly made up by $\mathrm{HCO}_{3}, \mathrm{Ca}$ and $\mathrm{SiO}_{2}$, reflecting the preferential contributions of carbonate and silicate chemical weathering to the Amazon River Basin. The main tributaries contributing to the TDS flux are the Marañon and Ucayali Rivers (approximately $50 \%$ of the TDS production over $14 \%$ of the Amazon basin area) due to the weathering of carbonates and evaporites drained by their Andean tributaries. An Andes-sedimentary area-shield TDS flux (and specific flux) gradient is observed throughout the basin and is first explained by the TDS concentration contrast between these domains, rather than variability in runoff. This observation highlights that, under tropical context, the weathering flux repartition is primarily controlled by the geomorphological/geological setting and confirms that sedimentary areas are currently active in terms of the production of dissolved load. The log relationships of concentration vs discharge have been characterized over all the studied stations and for all elements. The analysis of the slope of the relationship within the selected contexts reveals that the variability in TDS flux is mainly controlled by the discharge variability throughout the hydrological year. At the outlet of the basin, a clockwise hysteresis is observed for TDS concentration and is mainly controlled by $\mathrm{Ca}$ and $\mathrm{HCO}_{3}$ hysteresis, highlighting the need for a sampling strategy with a monthly frequency to accurately determine the TDS fluxes of the basin. The evaporite dissolution flux tends to be constant, whereas dissolved load fluxes released from other sources (silicate weathering, carbonate weathering, biological and/or atmospheric inputs) are mainly driven by variability in discharge. 
These results suggest that past and further climate variability had or will have a direct impact on the variability of dissolved fluxes in the Amazon. Further studies need to be performed to better understand the processes controlling the dynamics of weathering fluxes and their applicability to present-day concentration-discharge relationships at longer timescales.

Keywords Amazon basin - Andes · Sedimentary areas · Large rivers · Water chemistry $\cdot$ Dissolved solid flux . Weathering $\cdot$ Hydrological variability

\section{Introduction}

Solutes in large rivers are the main tracers of the element cycles of the Earth's critical zone at the continental scale. The estimation of their annual fluxes and the description of their concentration variability in response to the hydrology allow the determination of the weathering budget of contrasted environments and their responses to climate forcing. Because of its geological and climate heterogeneity, the Amazon basin can be considered as a "natural laboratory" allowing, for example, for the evaluation of the role of these environmental factors in matter exportation budgets. Moreover, the riverine solute exports are also an important source of nutrients for the oceans. At the global scale, the tropical basins are the main source of dissolved matter for the oceans (Gaillardet et al. 1999; Meybeck 2003). Among these tropical basins, the Amazon River is a major source of dissolved solids (e.g. Milliman and Farnsworth 2011).

Historically, the waters of the Amazon streams were classified based on their colour, which is related to their hydrochemical characteristics (transparency, $\mathrm{pH}$, conductivity, organic matter content and suspended matter) and to their ecological properties (e.g., Sioli 1964; Junk and Piedade 1997; Rios-Villamizar et al. 2014). These characteristics are in turn linked to the geological, geomorphological and biological properties of each sub-basin. The chemical composition of the main tributaries of the Amazon has allowed for the discrimination of the lithological sources of the dissolved load (Stallard and Edmond 1983, 1987; Edmond et al. 1996; Gaillardet et al. 1997; Mortatti and Probst 2003; Moquet et al. 2011). From these studies, it appears that the source of the dissolved load is mainly associated with silicate and carbonate weathering processes in the Andes. Nevertheless, Moquet et al. (2011) and Bouchez et al. $(2012,2014)$ suggested that the lowland sedimentary areas contribute to dissolved load production and that the $\mathrm{CO}_{2}$ consumption associated with the weathering of floodplain sediments is significant for the Amazon basin budget. From these studies, it also appears that the Andes silicate weathering flux is nearly proportional to the water flux, at least at the annual timescale (Moquet et al. 2014a).
However, the methods used to discriminate the sources of dissolved load are associated with significant uncertainties that might obscure the variability of the dissolved load along the hydrological cycle. These uncertainties are mainly associated with the definitions of the silicate end member compositions (Gaillardet et al. 1997; Bouchez and Gailladet 2014; Moon et al. 2014) and with the identification of the $\mathrm{SO}_{4}{ }^{2-}$ sources (Calmels et al. 2007; Beaulieu et al. 2011), especially in the case of the Andean basins (Moquet et al. 2011). In the present study, we explore the major element concentrations and fluxes without applying any correction/discrimination, and we focus on (1) the relationships between solute production and water flux at a timescale shorter than 1 year and on (2) the identification of the geographical areas producing each major solute.

Although the total suspended solids (TSS) dynamics and budget in the Amazon have largely been documented in the literature, both at the scale of the whole Amazon basin (e.g. Meade et al. 1985; Dunne et al. 1998; Filizola and Guyot 2009; Martinez et al. 2009; Filizola et al. 2011) and of the Andes (Guyot et al. 1996; Armijos et al. 2013a, b; Pepin et al. 2013; Santini et al. 2014), the total dissolved solid (TDS) variability in response to the hydrological cycle has been less examined. Some local studies have been performed in the shields (Markewitz et al. 2001), in the central plain area (Devol et al. 1995), at the outlet of the Amazon (Oltman et al. 1964; Oltman 1967; Gibbs 1967a, b) and on Andean rivers (Roche and Fernandez Jauregui 1988; Guyot et al. 1993; Townsend-Small et al. 2008; Aufdenkampe et al. 2007; Wilcke et al. 2001, 2003; Boy et al. 2008; Armijos et al. 2013b; Torres et al. 2015). Some studies provide a general overview of the temporal variability of TDS (e.g. Mortatti and Probst 2003; Tardy et al. 2005; Bustillo et al. 2010, 2011; Sanchez et al. 2015), but these results are restricted to a limited number of hydrological stations, and the Andean rivers are not specifically considered. To date, no study has presented an integrated view of the TDS variation as a function of discharge from the Andean basins to the outlet.

The present paper is a complementary study of Moquet et al. (2011) and Sanchez et al. (2015) and includes the database previously used by these authors. These studies estimate the weathering budget of the Andean basins (Moquet et al. 2011) and report estimates of dissolved load exports at the scale of the main tributaries (Sanchez et al. 2015). In the present study, we expanded our analysis to all the available contents of the geodynamical, hydrological and biogeochemical control of erosion/alteration and material transport in the Amazon, Orinoco and Congo basins-Environmental Research Observatory (HYBAM observatory) and PHICAB databases (>3,000 samples analysed for major elements over 34 gauging stations) at the outlet of the main geomorphological domains of the Amazon basin. We exploited this database following three main objectives. The first objective is to discuss the spatial variability of major element concentrations as a function of lithological, geomorphological and climate parameters. The 
second objective is to show the role of intra-annual hydro-climatological variability in the variability of TDS concentrations. The third objective is to determine the dissolved load fluxes exported by the Amazon basin and to identify their main geographical origin at the basin scale.

\section{Study area}

The Amazon basin covers 5.9 million $\mathrm{km}^{2}$ (Callède et al. 2010). It is located between $5^{\circ} 16^{\prime} \mathrm{N}$ and $20^{\circ} 28^{\prime} \mathrm{S}$, between $79^{\circ} 36^{\prime} \mathrm{W}$ and $50^{\circ} 15^{\prime} \mathrm{W}$ and across five main countries: Brazil (63\% of the surface area), Peru (16\%), Bolivia (12\%), Colombia (6\%) and Ecuador (2\%). Negligible portions of the basin are also included in Venezuela and Guyana. With an annual discharge of 6.5-6.6 $\times 10^{12} \mathrm{~m}^{3}$ year $^{-1}$ (Dai and Trenberth 2002; Callède et al. 2010), the Amazon River contributes $16-18 \%$ of the continental discharge to the oceans according to the global estimates of Dai and Trenberth (2002) and GRDC (2014). In the present work, the study area corresponds to the Amazon basin at the Óbidos station (Amazon River), Itaituba station (Tapajós River) and Altamira station (Xingu River) and covers 5.6 million $\mathrm{km}^{2}$, representing $94 \%$ of the entire Amazon basin (Fig. 1).
The Amazon basin can be separated into three geomorphological domains (Fig. 1 and Table 1):

1. The Andes (25\% of the basin) is the active orogenic zone and the major source of dissolved matter (due to the abundance of evaporite and carbonate outcrops; Gibbs 1967b; Stallard and Edmond 1987) and of suspended solids (e.g. Guyot et al. 1996; Armijos et al. 2013a, b). In the present study, this domain includes the Andean forelands (approximately half of this area), corresponding to Cenozoic back-arc basins (Roddaz et al. 2005), which make up the transition zone between the Andes and the central plain. This domain can behave as a sediment trap or as an erosional surface, according to the regional structural dynamics (Guyot 1993; Laraque et al. 2009; Baby et al. 2009; Armijos et al. 2013a, b; Santini et al. 2014).

2. The central plain domain (also named 'lowland'; $24 \%$ of the basin) forms a sedimentary basin for inputs coming from the Andes and, in much lower proportions, from the shields. It corresponds to the zone occupied by the main outflow channel of the Amazon toward the ocean (Filizola et al. 2011). This area is punctuated by floodplain lakes (várzeas) along the main channel of the Solimões and Amazon Rivers, which respond to the seasonal regime
Fig. 1 Topographic map of the Amazon basin and locations of the monitored gauging stations of the PHICAB program and HYBAM observatory (Gauging stations are detailed in Table 2). (M.d.D. Madre de Dios)

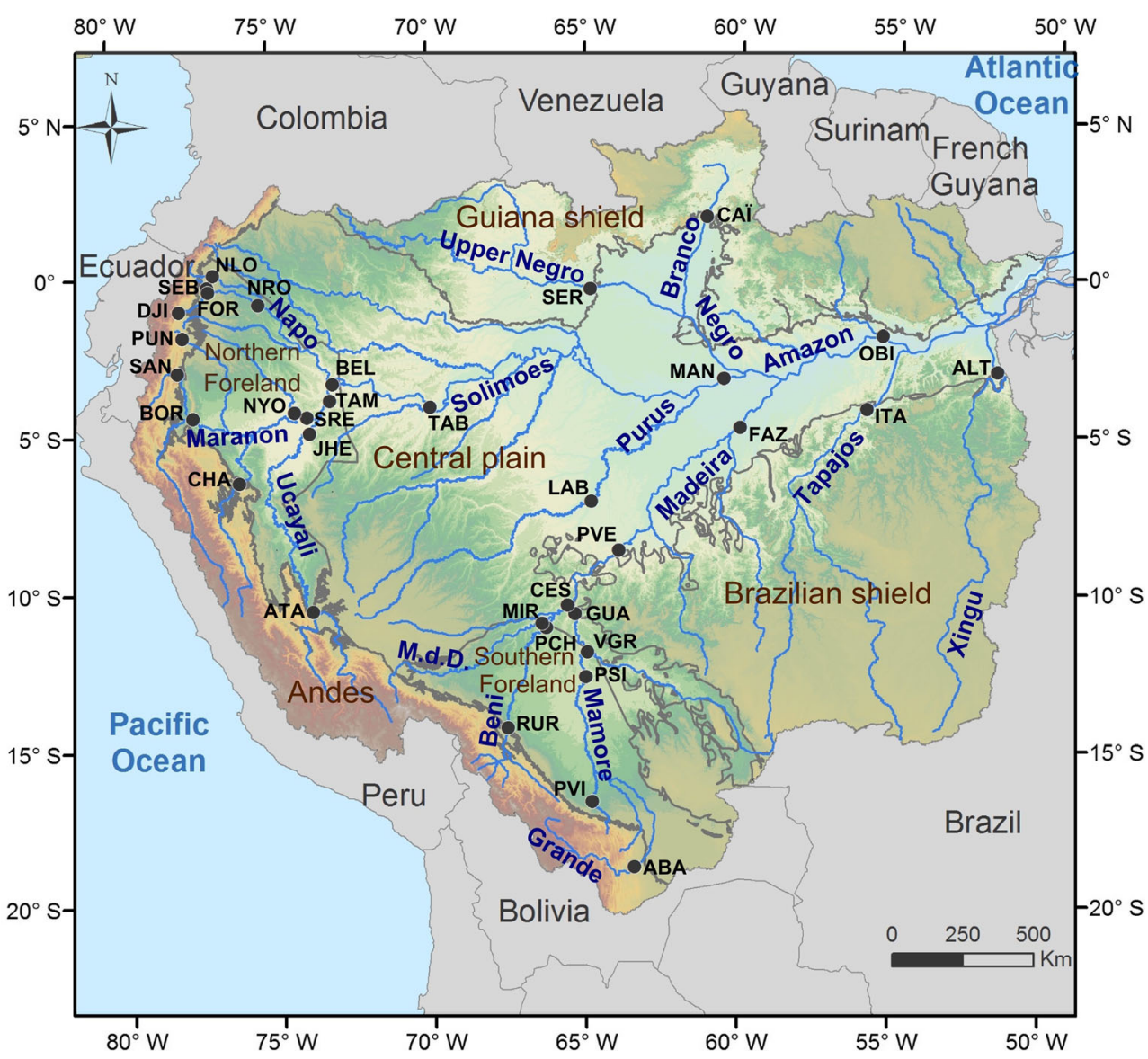


Table 1 Amazon basin and geomorphological domains (\% of the total Amazon basin area)

Geomorphological setting

\begin{tabular}{|c|c|c|c|c|c|c|c|c|}
\hline & \multicolumn{3}{|l|}{ Andean domain } & \multirow[t]{2}{*}{ Central plain } & \multicolumn{3}{|l|}{ Shields } & \\
\hline & Andes $(>400 \mathrm{~m})$ & Andean forelands & Total & & Brazilian shield & Guyana shield & Total & \\
\hline Area $\left(10^{6} \mathrm{~km}^{2}\right)$ & 683 & 779 & 1,462 & 1,452 & 853 & 2,186 & 3,039 & 5,953 \\
\hline$\%$ total Amazon basin & $12 \%$ & $13 \%$ & $25 \%$ & $24 \%$ & $14 \%$ & $37 \%$ & $51 \%$ & $100 \%$ \\
\hline
\end{tabular}

See Fig. 1 for the definition of domain boundaries

of inundation. These areas can play a significant role in the geochemical cycle of the Amazon sedimentary plain (Viers et al. 2005; Cullmann et al. 2006).

3. The Guiana and Brazilian shields (51\% of the basin) lie to the north and south of the Amazon corridor. They consist of two extensively eroded Precambrian terrains and have little influence on the inorganic dissolved and solid fluxes carried by the Amazon (Furch et al. 1982; Konhauser et al. 1994).

The hydrological network of the Amazon basin is organized according to five main tributaries: the Negro, Solimões, Madeira, Tapajós and Xingu Rivers. The following water budget and areas are compared with the corresponding number after the confluence of the Amazon, Tapajos and Xingu Rivers. It is based on the 2003-2012 discharge at the HYBAM observatory database at the outlet stations of these rivers reported in Table 2 and by Getirana et al. (2010) for the Negro River budget (1997-2006 period). The Negro River, near Manaus City ( $\sim 17 \%$ of the Amazon discharge and $13 \%$ of its area; Getirana et al. 2010), in the north of the basin, drains a large part of the Guyana shield. The main tributaries are the Branco River to the east and the Upper Negro River to the west. The Solimões River $(51 \%$ of the Amazon annual discharge and $39 \%$ of its area) drains the Northern and Central Andean sub-basins and the main part of the central plain. The main Andean Solimões tributaries are, from north to south, the Napo, Marañon and Ucayali Rivers. The Napo basin includes most of the active volcanoes of the basin. The Marañon and the Ucayali drain diverse lithologies and are especially marked by the occurrence of karstified carbonates and evaporite domes (Stallard and Edmond 1983). After the confluence of the Napo, Marañon and Ucayali, the main left bank tributaries of the Solimões are the Iça and Japura Rivers that drain the northern central plain and the small Colombian Andean basins. The main right bank tributaries are the Javarí, Jutaí, Juruá and Purus Rivers, which drain the centre part of the central plain. The Madeira River (13\% of the Amazon discharge and $23 \%$ of its area) drains the southern Andes and the western part of the Brazilian shield. The main Andean tributaries of the Madeira River are, from north to south, the Madre de Dios, the Beni and the Mamoré. Mamoré basin includes the semi-arid basin of the Grande River. The Tapajós and Xingu Rivers (6 and $4 \%$ of the Amazon discharge, respectively, and 8 and $8 \%$ of its area) drain the remaining area of the Brazilian shield in the south-southeastern part of the basin. These five main Amazon tributaries (Negro, Solimões, Madeira, Tapajos and Xingu) connect with the Amazon River in the central Amazon plain between the cities of Manaus and Belem (Brazil) from 1,200 to $150 \mathrm{~km}$ upstream from the estuary.

The climate of the Amazon basin is monsoonal and is controlled by the Southern American Monsoon System (SAMS). It depends on the seasonal variation of continentocean contrast in temperature and the seasonal migration of the intertropical convergence zone (ITCZ) southward (northward) during austral summer (winter) (Marengo 2004; Marengo et al. 2012). The ITCZ causes deep atmospheric convection with high rainfall and contributes a constant supply of moisture from the Atlantic Ocean to the Amazon Basin (Nogués Paegle et al. 2002; Vera et al. 2006). The Andean mountain chain acts as an orographic barrier and affects the atmospheric circulation and rainfall patterns at the continental scale (Insel et al. 2009; Garreaud et al. 2009). This orographic effect also induces a high heterogeneity of the rainfall distribution and intensity over the Andes and can favour either extremely humid (hotspots) or extremely dry (semi-arid) conditions in this region (Vera et al. 2006; Garreaud et al. 2009; Espinoza et al. 2009a).

At the scale of the basin, a north-south gradient is observed in the precipitation amount and seasonality (Espinoza et al. 2009a, b). Northern and northwestern Amazonia are exposed to high rainfall associated with a low seasonality, whereas southwestern and southern Amazonia experience lower rainfall associated with high seasonality and a dry (humid) season during austral winter (summer). This affects the hydrographs (Guimberteau et al. 2012) (Fig. 2). The maximum monthly discharges of the Tapajós, Madeira, Solimões and Negro Rivers occur in March, April, June and July, respectively. This time lag in maximum discharge reflects the south-north displacement of the ITCZ throughout the year (Fig. 2a) and is accompanied by a south-north gradient in the intensity of seasonality (the relative difference between the higher and lower monthly discharges) and in the specific discharge 


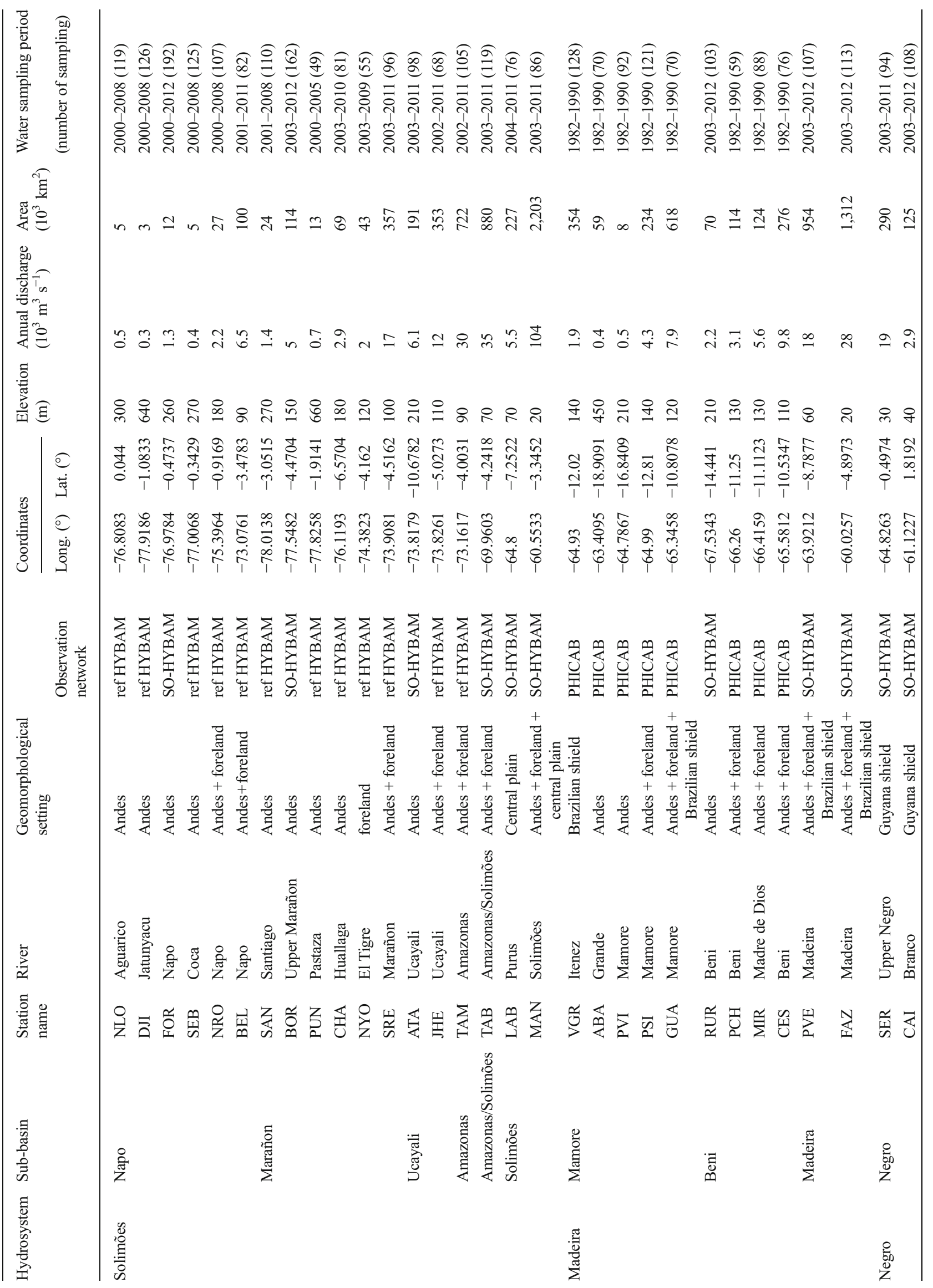




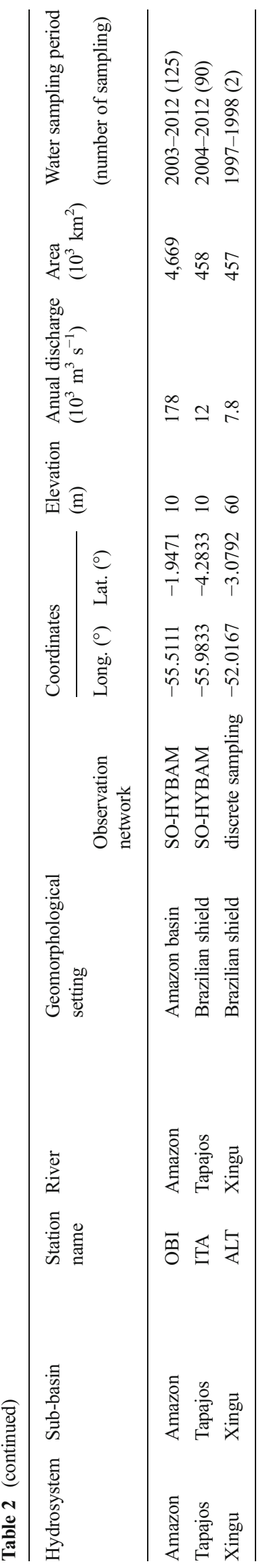

(Fig. 2b). Indeed, the Tapajós River experiences the highest seasonality and the lowest annual specific discharge, whereas the Negro River has the lowest seasonality but the highest specific discharge. The Amazon River at the Óbidos station displays the highest discharge between April and June. This maximum in discharge reflects the inputs of the Solimões River, but the seasonal variability of discharge of the Amazon at the Óbidos station is smoothed by the lag in time of the maximum discharge in the tributaries (the Madeira, Solimões and Negro Rivers) over the years (Fig. 2) and by the storage in the floodplains (Guimberteau et al. 2012).

The mean transit times of overland flow, shallow subsurface flow and groundwater have been estimated at the scale of the main Amazon tributaries based on the hydrograph separation using water-stable isotopes (Mortatti et al. 1997; Tardy et al. 2005; Bustillo et al. 2011). For example, Tardy et al. (2005) showed that the mean half-lives of water in the Amazon basin are approximately $22.2,32.6$ and 60.5 days for superficial runoff, hypodermic and groundwater reservoirs which annually contribute $29.5,47.8$ and $22.7 \%$ of the Amazon discharge, respectively. Recently, based on hydrological models, Paiva et al. (2013) showed that surface waters govern most of the monthly terrestrial water storage changes (56\%), followed by soil water $(27 \%)$ and ground water $(8 \%)$. In the channel, as the velocity of surface water ranges between 1 and $2 \mathrm{~m} \mathrm{~s}^{-1}$ (SO-HYBAM gauging database), the mean transit time from the Andes to the outlet of the basin (approximately 6,000 km) can be higher than 1 month.

\section{Material and methods}

In this study, we used the available data of the Programa Climatologico y Hidrologico de la Cuenca Amazonica de Bolivia (PHICAB) and HYBAM observatory (Geodynamical, hydrological and biogeochemical control of erosion/alteration and material transport in the Amazon, Orinoco and Congo basins-Environmental Research Observatory) frameworks (the HYBAM data are freely available at the HYBAM observatory website, http:// www.ore-hybam.org, and the PHICAB database is available in Guyot 1993). The PHICAB framework collected hydrochemical data at various gauging stations of the Upper Madeira basin between 1983 and 1992. The HYBAM framework has collected hydrochemical data since 2000. In the present study, we use the available data corresponding to the 2000-2012 period in the Solimões basin, at three stations in the Madeira basin and at Brazilian stations on the Negro, Amazon and Tapajós Rivers (Table 2). Importantly, the studied stations are not homogenously distributed throughout the Amazon basin. Among the 34 studied stations, 26 are located at the outlet of the Andean and foreland basins, seven stations record the inputs of the main Amazon tributaries, and Óbidos (OBI) is 
Fig. 2 a Monthly discharge of the Amazon River (right axis) and its main tributaries (left axis) and b monthly specific discharge of these rivers. Data are averaged for the 1983-2013 period (source: SO-HYBAM website)

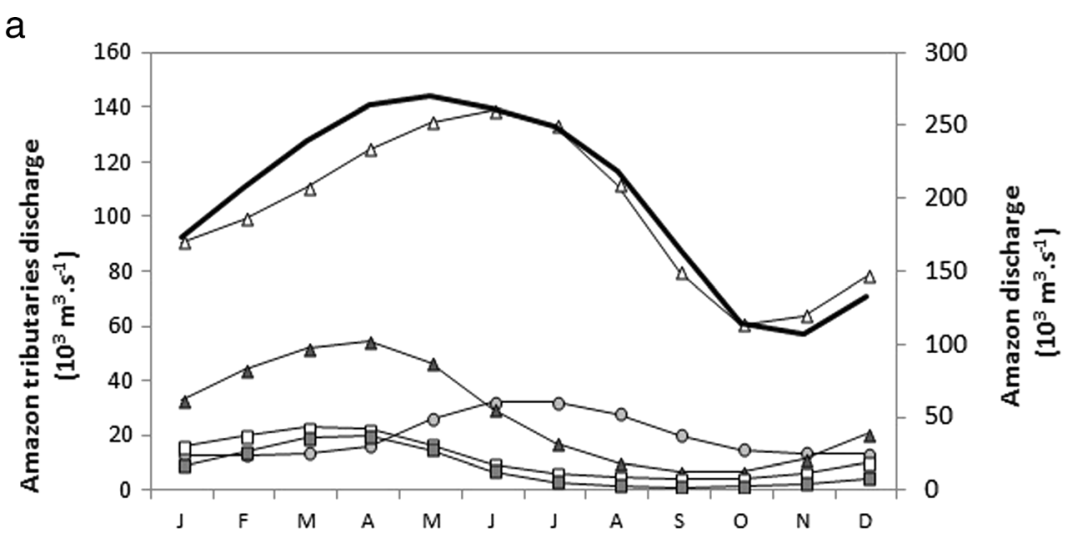

b

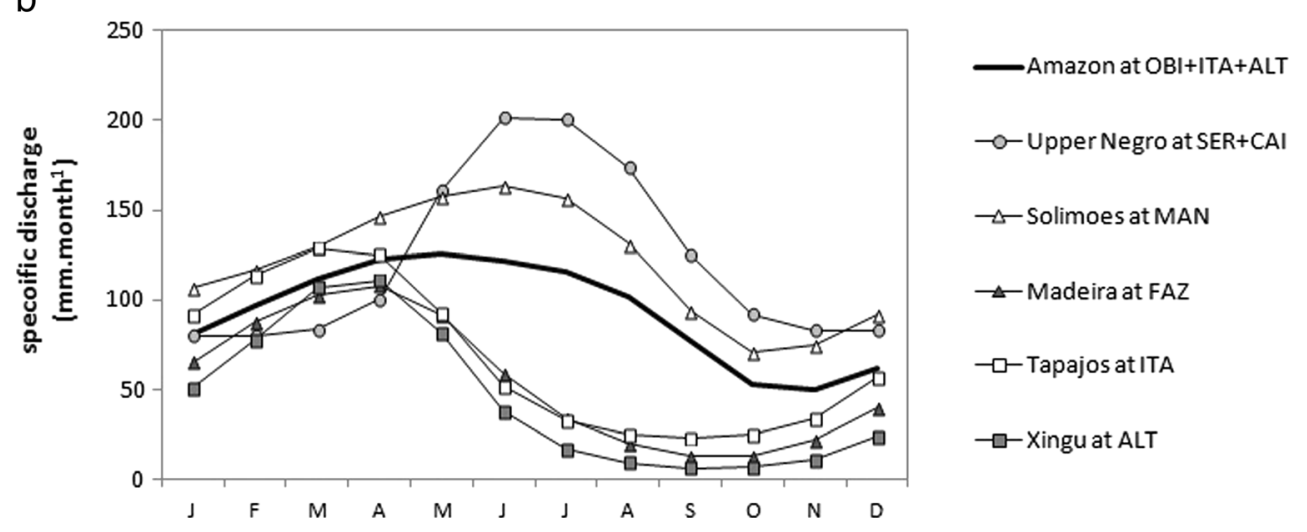

the main station recording the Amazon outputs. Each gauging station is hereafter named according to a three-letter code listed in Table 2.

\section{Hydrological data}

Water levels were collected daily or twice daily using a conventional hydrologic method. During the PHICAB period (1983-1992), gauging was accomplished using punctual velocity measurements with a mechanical current metre over the whole river section (Guyot 1993). For the 2000-2012 period, within the framework of the HYBAM observatory (http://www. ore-hybam.org), gauging was accomplished using a $600-\mathrm{kHz}$ (Peru, Bolivia and Brazil) or 1,200-kHz (Ecuador) acoustic Doppler current profiler (ADCP). The daily discharge series was then calculated from rating curves (discharge--water level relationship) using the Hydraccess software (Vauchel 2005; free download at the SO-HYBAM website).

\section{Sampling method and water chemistry analysis}

Conductivity and $\mathrm{pH}$ were measured every 10 days at a set of stations of the HYBAM framework, named the 'SO-HYBAM framework' and following a 3-month frequency at the other stations of the HYBAM network (named the 'reference HYBAM network') as well as at the PHICAB stations.
Remarkably, a conductivity time series is available at a frequency of 10 days since October 1994 at the Óbidos station.

Regarding the hydrochemical data, a sample of $650 \mathrm{ml}$ was collected monthly at each gauging station, with the exception of the ALT station (Xingu River), where we use only two sample analyses. The samples were filtered on site using a 0.45 - or $0.2-\mu \mathrm{m}$ porosity filter. Major element concentrations ( $\mathrm{Ca}, \mathrm{Mg}, \mathrm{Na}, \mathrm{K}, \mathrm{Cl}, \mathrm{SO}_{4}, \mathrm{HCO}_{3}$ and $\mathrm{Si}$ ) were determined at the Instituto de Investigacion en Quimica, Universidad Mayor de San Andres (IIQ-UMSA) laboratory (La Paz, Bolivia) for the 1983-1992 sampling period, at the Géoscience Environnement Toulouse laboratory (GET, France) for the 2000-2012 sampling period for Ecuadorian, Peruvian and Bolivian samples and at the Laboratory of Geochronology, Universidade de Brasilia (UnB) for the 2003-2012 sampling period for Brazilian samples. The samples collected during the PHICAB program were analysed according to the analytical procedure described in Guyot (1993): alkalinity was measured by acid titration, $\mathrm{Cl}^{-}$by mercuric thiocyanate colorimetry, $\mathrm{SO}_{4}{ }^{2-}$ by barium sulfate nephelometry, $\mathrm{Ca}^{2+}$ and $\mathrm{Mg}^{2+}$ by atomic absorption, $\mathrm{Na}^{+}$and $\mathrm{K}^{+}$by flame spectrometry and Si by ammonium molybdate colourimetry. The samples collected during the HYBAM program were analysed according to the procedure described in Cochonneau et al. (2006). $\mathrm{Cl}^{-}$ and $\mathrm{SO}_{4}{ }^{2-}$ concentrations were measured by ion chromatography, and $\mathrm{Na}^{+}, \mathrm{Ca}^{2+}, \mathrm{Mg}^{2+}, \mathrm{K}^{+}$and $\mathrm{Si}$ were analysed by inductively coupled plasma-atomic emission spectroscopy 
(ICP-AES). Alkalinity was determined by acid titration. The TDS concentration corresponds to the sum of the cations $(\mathrm{Ca}$, $\mathrm{Mg}, \mathrm{Na}$ and $\mathrm{K})$, the anions $\left(\mathrm{HCO}_{3}, \mathrm{SO}_{4}\right.$ and $\left.\mathrm{Cl}\right)$ and $\mathrm{SiO}_{2}$ concentrations, all expressed in milligram per litre. Based on the analyses of geostandards, the analytical error is less than $10 \%$ for both sampling periods.

We observed that TDS and conductivity are significantly correlated $\left(r^{2}=0.86 ; p\right.$ values $\left.<0.01 ; N=1,782\right)$, considering the whole database, with the exception of one outlier (when conductivity or $\mathrm{TDS}>$ average $+3 \sigma$; $\mathrm{ABA}$ station):

$\operatorname{TDS}\left(\mathrm{mg} \mathrm{L}^{-1}\right)=0.8 \times$ conductivity $\left(\mu \mathrm{S} \mathrm{cm} \mathrm{cm}^{-1}\right) \pm 21 \mathrm{mg} \mathrm{L}^{-1}$

Here, the error is defined as the mean absolute error (MAE) of the relationship.

In the present study, we use the conductivity as a proxy for TDS concentration to describe the concentration $(C)$ vs discharge $(Q)$ relationship because of the higher frequency of conductivity acquisition (10 days), allowing a precise characterization of the total solute dynamics throughout the hydrological year.

\section{Annual flux calculation}

The Amazon TDS flux corresponds to the sum of the inputs of the Amazon River at the OBI station, the Tapajós River at the ITA station and the Xingu River at the ALT station. To calculate the annual flux of each solute at each station, we first estimated the monthly flux based on the multiplication of the instantaneous concentrations obtained at a monthly period by the monthly discharge calculated from the sum of daily discharges (method M1C in Table S1 of the supplementary material). We then calculated the interannual average of monthly fluxes. We finally added the 12 monthly flux averages to evaluate the mean annual flux.

At two stations (the OBI and ITA stations), we also performed three other annual flux calculations for TDS (Table S1) to compare the effect of the flux calculation methods based on the same dataset in the period 2003-2012. The results are presented in Table S2. The method M1A corresponds to the mean concentration of the overall data multiplied by the mean monthly discharge; then, we added the 12 monthly flux averages to evaluate the mean annual flux. The method M1B corresponds to the monthly concentration interannual average multiplied by the mean monthly discharge interannual average; then, we added the 12 monthly flux averages to evaluate the mean annual flux. The method M2A corresponds to the application of the $C=a Q^{b}$ relationship (see the following section) based on the daily discharge database. The daily flux is then calculated based on the multiplication of $\mathrm{Cj}$ and $\mathrm{Qj}$, and the annual flux corresponds to the sum of the daily fluxes.
The error associated with these estimates corresponds to the sum of the analytical error $(<10 \%)$ and the error associated with the discharge measurements. The discharge measurement errors at OBI, ITA and ALT were estimated to be $\pm 3, \pm 10.7$ and $\pm 9.8 \%$, respectively, by Callède et al. (2010). The weighted discharge measurement error of the sum of the discharge at these three stations was therefore $\pm 4 \%$. A maximum of error of $14 \%$ is estimated. Indeed, regardless of the calculation method performed, if we compare the sum of the annual solute fluxes calculated upstream of the OBI station (at the MAN, FAZ, CAI and SER stations) with the solute fluxes calculated at the OBI station, the upstream flux is equal to the OBI fluxes within $10 \%$ ((flux OBI-flux upstream)/flux OBI) for TDS, $\mathrm{Cl}, \mathrm{SO}_{4}, \mathrm{HCO}_{3}, \mathrm{Ca}, \mathrm{Mg}$ and $\mathrm{Na}$. Only the upstream annual fluxes of $\mathrm{K}$ and $\mathrm{Si}$ are 11 and $26 \%$ lower than those at the flux measured at OBI station most likely due to significant $\mathrm{K}$ and $\mathrm{Si}$ inputs by the surface basin included between these stations.

\section{$C$ vs $Q$ relationships}

Water discharge is an important factor affecting the variation of riverine material fluxes. The time series of dissolved concentrations allows us to derive the relationships between major element concentrations and river discharge. These relationships are functionally described using:

$$
C_{\mathrm{i}}=a Q_{\mathrm{i}}^{b} \quad \text { or } \quad \log \left(C_{\mathrm{i}}\right)=10^{a}+b \log \left(Q_{\mathrm{i}}\right)
$$

where $C_{\mathrm{i}}$ is the instantaneous (daily) concentration of the studied major element, $Q_{\mathrm{i}}$ is the daily discharge corresponding to the sampling date and $a$ and $b$ are the regression coefficients. Such relationships have been reported for several rivers to characterize the variation of the solute concentration in response to discharge variability (e.g. Walling and Webb 1983; Nkounkou and Probst 1987; Roy et al. 1999; Chen et al. 2002; Godsey et al. 2009; Gislason et al. 2009; Clow and Mast 2010; Li et al. 2012; Laraque et al. 2013; Moon et al. 2014). These relationships between flow and load have important implications for predicting the fluxes of chemical constituents to receiving water bodies due to variable environmental conditions (Godsey et al. 2009; Jawitz and Mitchell 2011). In this paper, we used the slope $b$ of the $C-Q$ regression as an index, allowing for the characterization of the first-order response of the production of Amazonian solutes to changes in discharge. Indeed, the slope is a measure of the first-order degree to which concentration responds to a change in discharge. The larger the slope, the less sensitive is the concentration. When $b \sim 0$, the concentration variability is low and independent of discharge. This behaviour, called 'chemostatic' (Godsey et al. 2009), reflects a constant solute concentration despite variations in discharge. When $b$ -1 , concentration decreases with increasing discharge, corresponding to a total dilution pattern and reflecting a constant 
solute flux despite variations in discharge. When $b>0$, concentration increases with increasing discharge, as generally observed for suspended load concentrations (e.g. Armijos et al. 2013b).

Based on a global compilation that included HYBAM for the Amazon at the OBI station, Moon et al. (2014) suggested that at least 40 paired concentration-discharge measurements are needed to calculate unbiased weathering rates. Following this criterion, the data from the PUN, PCH and ALT stations are excluded for the analysis. Moreover, the $C-Q$ relationship at NYO station is not significant (Moquet et al. 2014b). In the supplementary material S3, we reported the regression parameters with their related standard errors (SE) on $a$ and $b$ values and the mean absolute percentage error (MAE\%) of each regression. Because of the occurrence of hysteresis behaviour at the OBI station (see below), we did not use this method to calculate the annual Amazon fluxes.

\section{Results}

\section{Hydrochemical characteristics}

The description presented hereafter is based on the PHICAB and HYBAM monitoring networks and partly summarizes results already reported in Moquet et al. (2011), for the Andean tributaries, and in Sanchez et al. (2015), for some of the downstream stations. Even if slight differences in the mean concentration values are observed between the present study and the previous ones due to the actualization of the database, the values measured in both studies are commensurate. Hydrochemical characteristics are reported in Table 3 and are illustrated in Fig. 3.

The $\mathrm{pH}$ of the river water samples ranges between 4.8 and 7.9 (median value for each gauging stations). The highest value is recorded in the semi-arid basin of the Grande River (ABA station, Upper Madeira River), which is characterized by significant carbonates and Neogene evaporites (Moquet et al. 2011). The lowest $\mathrm{pH}$ values are recorded in the Upper Negro River at the SER station, which is characterized by a high abundance of arenosol/podzol soils and is known to release waters with high organic matter concentrations (e.g. Stallard and Edmond 1983; Moreira-Turcq et al. 2003). At the other stations, the $\mathrm{pH}$ is closer to neutral conditions, with slightly alkaline water in the Andean tributaries and slightly acid water in the rivers of the central plain and shield. These values are coherent with previous observations (Sioli 1964; Junk and Piedade 1997; Rios-Villamizar et al. 2014).

The TDS concentration (and conductivity) is contrasted throughout the basin (Fig. 3 and Table 3). The highest mean value (TDS at $\mathrm{ABA}=396 \mathrm{mg} \mathrm{L}^{-1}$ ) is recorded in the semi-arid basin of the Grande River (Upper Madeira), and the lowest value (TDS at $\mathrm{SER}=6.5 \mathrm{mg} \mathrm{L}^{-1}$ ) is recorded in the podzolic/ arenitic basin of the Upper Negro River. The other TDS values decrease as follows: Marañon-Ucayali $(\operatorname{TDS}=63$ to $\left.222 \mathrm{mg} \mathrm{L}^{-1}\right)>$ Napo $\left(\mathrm{TDS}=64\right.$ to $\left.99 \mathrm{mg} \mathrm{L}^{-1}\right)=$ Upper Madeira (TDS $=63$ to $109 \mathrm{mg} \mathrm{L}^{-1}$ ) $>$ central plain tributaries (TDS of Purus at $\mathrm{LAB}=52 \mathrm{mg} \mathrm{L}^{-1}$ ) > shield tributaries (Negro, Branco, Tapajós and Xingu Rivers; TDS $=22$ to $48 \mathrm{mg} \mathrm{L}^{-1}$ ). This hierarchy reflects the lithological/geomorphological characteristics of the river basins. Importantly, this hierarchy is based only on the monitored tributaries that integrate the upstream sub-basins. Intra-basin concentration heterogeneities have previously been observed, especially in the Andes (e.g. Stallard and Edmond 1983; Guyot et al. 1998). The Grande River (Madeira Andes) is characterized by significant evaporite deposits and a semi-arid climate. The Marañon and the Ucayali (Andean tributaries) drain large evaporite and carbonate outcrops. The Napo basin (Andean tributaries) includes the main active volcanoes of the basin. The central plain tributaries (e.g. Purus River) drain old deposits of silicate sediments, initially exported from the Andean area. These waters are fairly diluted. As a consequence, the Solimões (TAM, TAB and MAN) and Madeira (PVE and FAZ) stations are affected by dilution associated with the foreland and central plain inputs. The tributaries in the shields (Negro, Branco, Tapajós and Xingu Rivers at the SER, CAI, ITA and ALT stations, respectively) are characterized by highly diluted waters. Even if all the basins of the shields exhibit low TDS concentrations $\left(<35 \mathrm{mg} \mathrm{L}^{-1}\right)$, they can be separated into two groups: the Branco, Tapajós and Xingu Rivers (CAI, ITA and ALT stations, respectively; $22-35 \mathrm{mg} \mathrm{L}^{-1}$ ) exhibit higher TDS concentrations than the Upper Negro River (SER station; $6 \mathrm{mg} \mathrm{L}^{-1}$ ).

With the exception of some specific contexts, $\mathrm{Ca}^{2+}, \mathrm{Mg}^{2+}$, $\mathrm{Na}^{+}, \mathrm{SO}_{4}{ }^{2-}, \mathrm{Cl}^{-}$and $\mathrm{HCO}_{3}{ }^{-}$concentrations follow the same hierarchy as the conductivity and TDS. However, high relative chlorine and sodium contents are recorded in the Marañon subbasin in the Huallaga River (CHA station), which drains large evaporitic domes (Benavides 1968) and in the El Tigre River (NYO station), which was characterized by formation water released from oil extraction activity until February 2009 (Moquet et al. 2014b) (Fig. 3). These two basins exhibit high $\mathrm{Cl}$ and $\mathrm{Na}$ concentrations $\left(\mathrm{Cl}^{-}\right.$and $\left.\mathrm{Na}^{+} \geq 800 \mu \mathrm{mol} \mathrm{L}^{-1}\right)$ and a $1: 1 \mathrm{Cl} / \mathrm{Na}$ ratio characteristic of halite dissolution. $\mathrm{SO}_{4}{ }^{2-}$ concentrations are generally higher than $50 \mu \mathrm{mol} \mathrm{L}^{-1}$ in all Andean sub-basins. This element is released by dissolution of evaporites (gypsum) and by pyrite oxidation (Berner and Berner 1987; Moquet et al. 2011).

In contrast with TDS and the $\mathrm{Ca}^{2+}, \mathrm{Mg}^{2+}, \mathrm{Na}^{+}, \mathrm{SO}_{4}{ }^{2-}, \mathrm{Cl}^{-}$ and $\mathrm{HCO}_{3}{ }^{-}$concentrations, $\mathrm{K}^{+}$and $\mathrm{Si}$ do not follow the same trend. The highest concentrations of dissolved $\mathrm{Si}$ are measured in the basins draining volcanic areas (the Upper Napo and the PUN and SAN stations of the Marañon basin), and the lowest values are measured in the Upper Negro River. Despite the high geographical diversity (lithology, geomorphology, climate, etc.), all the other basins exhibit a low spatial variability of dissolved Si concentration. High $\mathrm{K}^{+}$concentrations are measured in the El Grande River (ABA station), probably 
Table 3 Physico-chemical characteristics and average dissolved solid concentrations for the monitored stations (for the ALT station, the values for the two analysed samples are presented)

\begin{tabular}{lllllllllllll}
\hline $\begin{array}{l}\text { Station } \\
\text { name }\end{array}$ & $\mathrm{pH}$ & $\begin{array}{l}\text { Cond } \\
\mu \mathrm{S} \mathrm{cm}^{-1}\end{array}$ & $\begin{array}{l}\mathrm{Ca} \\
\mu \mathrm{mol} \mathrm{L}\end{array}$ & $\mathrm{Mg}$ & $\mathrm{Na}$ & $\mathrm{K}$ & $\mathrm{Cl}$ & $\mathrm{SO}_{4}$ & $\mathrm{HCO}_{3}$ & $\mathrm{SiO}_{2}$ & $\begin{array}{l}\mathrm{TDS}^{-1} \\
\mathrm{mg} \mathrm{L}^{-1}\end{array}$
\end{tabular}

Median (min-max) $\operatorname{Avg} \pm \sigma$

\begin{tabular}{|c|c|c|c|c|c|c|c|c|c|c|c|}
\hline NLO & $7.1(6-8.8)$ & $92 \pm 16$ & $318 \pm 55$ & $57 \pm 11$ & $98 \pm 30$ & $38 \pm 38$ & $31 \pm 64$ & $48 \pm 13$ & $724 \pm 140$ & $208 \pm 42$ & $80 \pm 13$ \\
\hline DJI & $7.2(5-8.7)$ & $88 \pm 31$ & $233 \pm 133$ & $52 \pm 22$ & $114 \pm 47$ & $41 \pm 34$ & $25 \pm 19$ & $49 \pm 31$ & $648 \pm 253$ & $231 \pm 79$ & $77 \pm 24$ \\
\hline FOR & $7(6.3-7.8)$ & $63 \pm 19$ & $189 \pm 41$ & $49 \pm 13$ & $116 \pm 48$ & $36 \pm 18$ & $20 \pm 12$ & $29 \pm 10$ & $544 \pm 123$ & $251 \pm 46$ & $64 \pm 10$ \\
\hline SEB & $7.2(6.5-8.1)$ & $118 \pm 19$ & $339 \pm 68$ & $110 \pm 32$ & $172 \pm 49$ & $42 \pm 15$ & $66 \pm 44$ & $110 \pm 42$ & $781 \pm 129$ & $289 \pm 54$ & $98 \pm 15$ \\
\hline NRO & $6.8(6.2-7.5)$ & $71 \pm 24$ & $192 \pm 46$ & $68 \pm 42$ & $133 \pm 59$ & $36 \pm 7$ & $29 \pm 18$ & $42 \pm 18$ & $566 \pm 262$ & $278 \pm 98$ & $71 \pm 25$ \\
\hline BEL & $6(5.1-7.3)$ & $43 \pm 12$ & $129 \pm 46$ & $48 \pm 17$ & $93 \pm 65$ & $26 \pm 13$ & $43 \pm 79$ & $25 \pm 13$ & $404 \pm 114$ & $205 \pm 39$ & $50 \pm 10$ \\
\hline SAN & $7.4(6.3-9.6)$ & $71 \pm 13$ & $207 \pm 45$ & $60 \pm 11$ & $118 \pm 31$ & $23 \pm 8$ & $27 \pm 8$ & $50 \pm 12$ & $526 \pm 135$ & $200 \pm 52$ & $63 \pm 10$ \\
\hline BOR & $7.1(5.9-8.2)$ & $172 \pm 56$ & $615 \pm 249$ & $99 \pm 28$ & $217 \pm 100$ & $27 \pm 6$ & $128 \pm 144$ & $110 \pm 78$ & $1,337 \pm 476$ & $192 \pm 61$ & $140 \pm 42$ \\
\hline PUN & $7.2(5.4-8.8)$ & $111 \pm 29$ & $215 \pm 58$ & $181 \pm 67$ & $308 \pm 107$ & $43 \pm 12$ & $74 \pm 29$ & $105 \pm 37$ & $826 \pm 247$ & $260 \pm 89$ & $100 \pm 27$ \\
\hline HA & $6.8(6-8)$ & $292 \pm 76$ & $784 \pm 126$ & $120 \pm 45$ & $1,054 \pm 745$ & $33 \pm 9$ & $949 \pm 745$ & $181 \pm 99$ & $1,595 \pm 266$ & $180 \pm 25$ & $222 \pm 52$ \\
\hline NYO & $5.7(4.8-7.5)$ & $138 \pm 95$ & $144 \pm 146$ & $48 \pm 36$ & $788 \pm 543$ & $21 \pm 7$ & $897 \pm 731$ & $28 \pm 48$ & $378 \pm 389$ & $170 \pm 45$ & $103 \pm 62$ \\
\hline SRE & $6.8(5.4-9.6)$ & $160 \pm 54$ & $489 \pm 144$ & $83 \pm 25$ & $532 \pm 290$ & $27 \pm 6$ & $532 \pm 432$ & $72 \pm 40$ & $1,100 \pm 281$ & $190 \pm 43$ & $145 \pm 33$ \\
\hline TA & $7.4(5.9-8.2)$ & $254 \pm 68$ & $792 \pm 209$ & $179 \pm 57$ & $490 \pm 258$ & $44 \pm 9$ & $334 \pm 203$ & $294 \pm 129$ & $1,571 \pm 361$ & $211 \pm 51$ & $196 \pm 42$ \\
\hline JHE & $6.6(5.6-7.4)$ & $209 \pm 112$ & $713 \pm 327$ & $129 \pm 62$ & $386 \pm 262$ & $37 \pm 10$ & $282 \pm 225$ & $153 \pm 93$ & $1,440 \pm 757$ & $161 \pm 41$ & $155 \pm 80$ \\
\hline TAM & $6.7(5.8-8)$ & $194 \pm 47$ & $652 \pm 101$ & $113 \pm 22$ & $446 \pm 180$ & $34 \pm 9$ & $365 \pm 167$ & $116 \pm 29$ & $1,358 \pm 224$ & $182 \pm 33$ & $158 \pm 23$ \\
\hline $\mathrm{TAB}$ & $7.4(6.2-8.1)$ & $147 \pm 23$ & $508 \pm 101$ & $99 \pm 22$ & $343 \pm 136$ & $33 \pm 5$ & $231 \pm 99$ & $87 \pm 24$ & $1,082 \pm 207$ & $211 \pm 72$ & $128 \pm 16$ \\
\hline $\mathrm{AB}$ & $6.9(5.9-7.7)$ & $42 \pm 22$ & $149 \pm 79$ & $51 \pm 26$ & $78 \pm 41$ & $28 \pm 8$ & $16 \pm 14$ & $25 \pm 15$ & $355 \pm 209$ & $230 \pm 86$ & $51 \pm 18$ \\
\hline IAN & $6.9(4-7.8)$ & $77 \pm 18$ & $254 \pm 64$ & $57 \pm 12$ & $159 \pm 60$ & $25 \pm 7$ & $110 \pm 50$ & $45 \pm 20$ & 135 & $158 \pm 23$ & $70 \pm 12$ \\
\hline VGR & $6.7(3.6-9.6)$ & $40 \pm 20$ & $63 \pm 73$ & $47 \pm 34$ & $=68$ & $51 \pm 27$ & $65 \pm 76$ & $29 \pm 59$ & 163 & $174 \pm 71$ & $47 \pm 16$ \\
\hline $\mathrm{BA}$ & 7.9 & 64 & 1,091 & $1,052 \pm 636$ & 66 & $119 \pm 45$ & 70 & $1,149 \pm 937$ & 2,34 & 155 & \pm 131 \\
\hline VI & $6.6(3.8-10)$ & 24 & $1 \pm 107$ & $89 \pm 43$ & $202 \pm 199$ & $40 \pm 48$ & $178 \pm 545$ & $160 \pm 108$ & $273 \pm 197$ & $169 \pm 84$ & $63 \pm 33$ \\
\hline PSI & $7.6(6.4-9.7)$ & $142 \pm 51$ & $257 \pm 103$ & $199 \pm 83$ & $289 \pm 181$ & $60 \pm 19$ & $138 \pm 144$ & $144 \pm 124$ & $878 \pm 388$ & $141 \pm 49$ & $109 \pm 41$ \\
\hline UA & $7.6(5.7-9.6)$ & $91 \pm 32$ & $171 \pm 73$ & $118 \pm 52$ & $168 \pm 92$ & $50 \pm 10$ & $72 \pm 57$ & $93 \pm 76$ & $575 \pm 174$ & $160 \pm 79$ & $73 \pm 21$ \\
\hline UR & $7(6.2-8.4)$ & $128 \pm 13$ & $270 \pm 66$ & $169 \pm 49$ & $164 \pm 57$ & $29 \pm 9$ & $30 \pm 16$ & $264 \pm 85$ & $556 \pm 123$ & $146 \pm 22$ & $89 \pm 20$ \\
\hline $\mathrm{PCH}$ & $7.2(5.1-8.8)$ & $122 \pm 24$ & $264 \pm 83$ & $174 \pm 79$ & $148 \pm 69$ & $43 \pm 13$ & $66 \pm 60$ & $130 \pm 95$ & $730 \pm 148$ & $157 \pm 71$ & $89 \pm 16$ \\
\hline MIR & $7.2(4-10.3)$ & $77 \pm 28$ & $197 \pm 82$ & $78 \pm 42$ & $125 \pm 70$ & $40 \pm 15$ & $86 \pm 98$ & $60 \pm 43$ & $709 \pm 337$ & $181 \pm 54$ & $79 \pm 28$ \\
\hline CES & $7.1(4.7-10)$ & $86 \pm 22$ & $194 \pm 63$ & $103 \pm 42$ & $119 \pm 57$ & $40 \pm 12$ & $75 \pm 81$ & $83 \pm 56$ & $630 \pm 156$ & $173 \pm 65$ & $75 \pm 15$ \\
\hline PVE & $7.2(5.8-8)$ & $77 \pm 22$ & $214 \pm 76$ & $113 \pm 36$ & $126 \pm 51$ & $38 \pm 6$ & $28 \pm 21$ & $101 \pm 55$ & $534 \pm 158$ & $178 \pm 64$ & $69 \pm 17$ \\
\hline FAZ & $6.9(5.9-7.6)$ & $53 \pm 17$ & $139 \pm 46$ & $81 \pm 25$ & $112 \pm 58$ & $36 \pm 8$ & $26 \pm 16$ & $57 \pm 40$ & $381 \pm 112$ & $150 \pm 39$ & $50 \pm 11$ \\
\hline SER & $4.8(3.6-6.7)$ & $7 \pm 4$ & $10 \pm 5$ & $5 \pm 2$ & $26 \pm 37$ & $10 \pm 7$ & $7 \pm 4$ & $2 \pm 5$ & $18 \pm 19$ & $65 \pm 12$ & $6 \pm 1$ \\
\hline CAI & $6.6(5.2-7.6)$ & $27 \pm 9$ & $41 \pm 9$ & $34 \pm 7$ & $98 \pm 41$ & $36 \pm 14$ & $22 \pm 11$ & $7 \pm 9$ & $224 \pm 77$ & $229 \pm 38$ & $35 \pm 7$ \\
\hline OBI & $6.9(6.2-7.5)$ & $51 \pm 12$ & $151 \pm 43$ & $44 \pm 13$ & $97 \pm 36$ & $23 \pm 5$ & $58 \pm 26$ & $32 \pm 15$ & $381 \pm 102$ & $163 \pm 49$ & $48 \pm 11$ \\
\hline ITA & $6.5(5.3-7.5)$ & $16 \pm 4$ & $32 \pm 17$ & $23 \pm 5$ & $32 \pm 11$ & $22 \pm 4$ & $17 \pm 14$ & $2 \pm 2$ & $143 \pm 52$ & $153 \pm 21$ & $22 \pm 4$ \\
\hline ALT & $(6.7-6.6)$ & $14-17$ & $31-32$ & $24-23$ & $35-64$ & $19-25$ & $14-15$ & $2-2$ & 174-192 & $118-153$ & $22-26$ \\
\hline
\end{tabular}

due to the high inputs of evaporite dissolution (Guyot 1993). In the other rivers, the $\mathrm{K}^{+}$concentration has low spatial variability. These elements can both reflect silicate weathering and vegetation inputs (Berner and Berner 1987; Lucas 2001; Chaudhuri et al. 2007). With the exception of some specific contexts (volcanic area and upper Negro River for Si and Grande River for $\mathrm{K}^{+}$), the $\mathrm{Si}$ and $\mathrm{K}^{+}$concentrations are relatively homogenous over areas characterized by high heterogeneity in lithology, geomorphology or climate. This difference in the spatial variability in concentration between $\mathrm{K}^{+}$and $\mathrm{Si}$ and the other major elements was also observed by Guyot et al. (1998) in the Madeira basin.

\section{$C-Q$ relationships}

Regression parameters of Eq. 1 were determined for TDS concentration, conductivity and all elements over all gauging stations (Fig. 4). 
Fig. 3 Dissolved load chemical composition and average conductivity values $( \pm$ standard deviation) of the monitored rivers
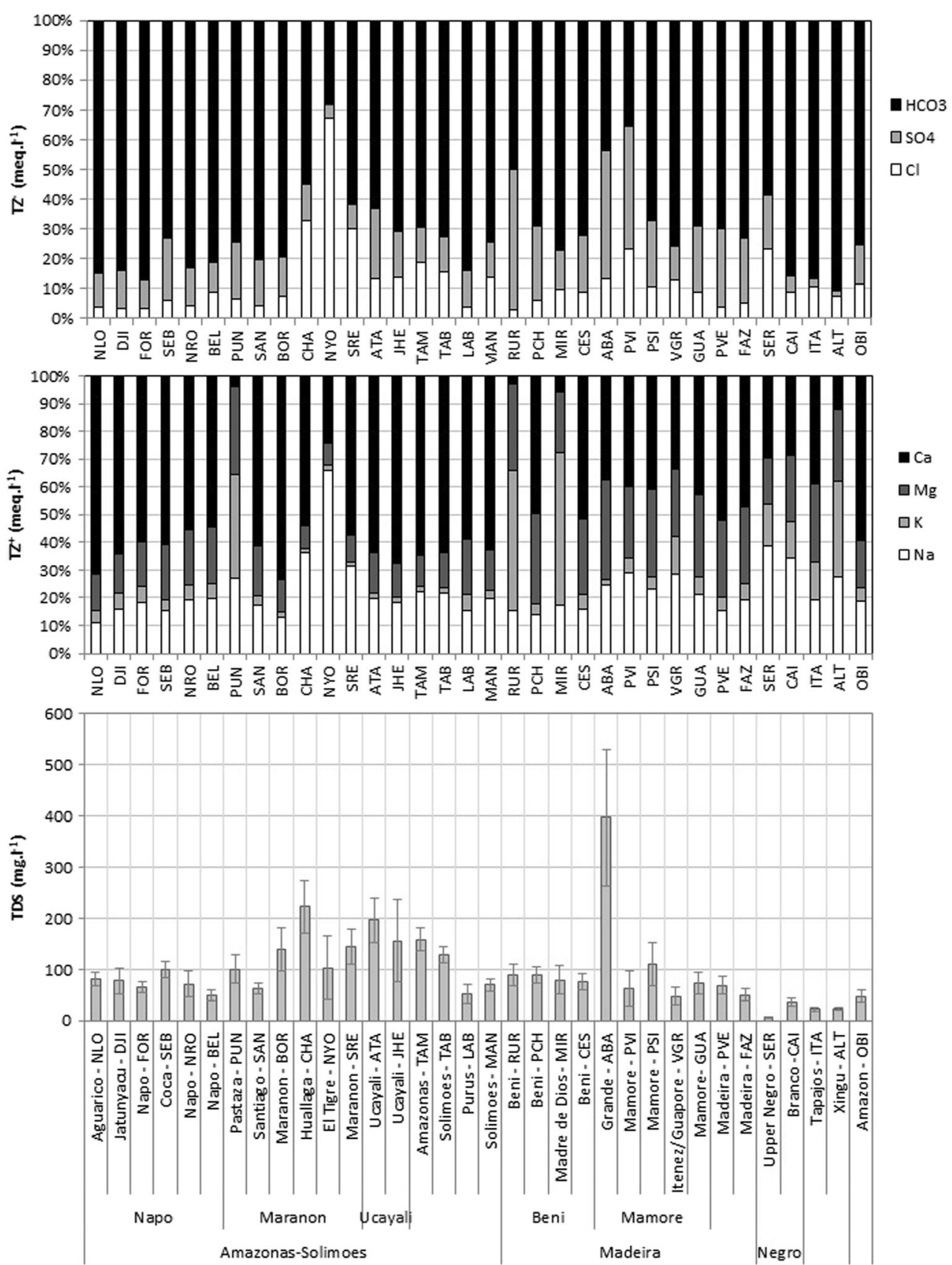

The slope $b$ of the $C-Q$ relationship varies from station to station and from element to element, but $b$ value is usually between 0 and -1 in the Amazon basin, indicating that concentrations remain nearly constant or respond inversely to changes in discharge, consistently with observations at a global scale (Meybeck et al. 1996).

The definition of a $C-Q \log$ relationship is not adapted for all elements in all contexts to reproduce the measured concentration. A MAE greater than $50 \%$ is generally measured for $\mathrm{Cl}$ and/or $\mathrm{SO}_{4}$ in the Solimões upper basin at the SRE and BEL stations and in the upper Madeira basin and for most of the elements at the SER station, indicating that the observed $C-Q$ relationships are non-linear in $\log -\log$ space (Fig. 4). At the
SER station, this observation can be explained by the very low concentrations and high relative error. At the other stations with high MAE, the $C-Q$ relationships are simply not univocal.

As TDS and conductivity are correlated, they generally exhibit similar $b$ values under the \pm 1 SE uncertainties (Figs. 4 and 5 ). Throughout the basin, the TDS $b$ value varies between -0.42 \pm 0.07 and $0.02 \pm 0.04$ but is generally close to -0.20 . This implies that the TDS variability is lower than the discharge variability and that, at first order and as observed in other contexts (e.g. Markewitz et al. 2006; Yuan et al. 2007), the TDS flux variability is controlled by discharge along the hydrological cycle. 
Figure 5 shows conductivity vs discharge at nine selected stations representative of the main geomorphological contexts of the Amazon basin. The Solimões River (BOR, TAB and MAN stations) exhibits the highest conductivity values. In its Andean part (BOR station), the conductivity is highly variable. This behaviour can reflect the spatial and temporal heterogeneity of rainfall and solute sources. Downstream at the TAB and MAN stations, lower conductivity values can reflect the dilution effect due to the contribution of tributaries draining sedimentary areas. Nevertheless, in response to the hydrological cycle at all these stations, the variability of conductivity remains low in comparison with discharge variability, and $b$ value is lower than -0.2 .

In the Madeira sub-basins, the conductivity $-Q$ slope $b$ is nearly zero at the RUR station, representing the Andean part of the sub-basin, and decreases to -0.2 in the central plain. At the RUR station, even if the slope $b$ is close to zero, concentration is variable, as previously observed by Guyot et al. (1993), and two regimes can be distinguished. For discharge lower than $1,800 \mathrm{~m}^{3} \mathrm{~s}^{-1}$, the conductivity is close to the simple dilution curve. For discharge higher than $1,800 \mathrm{~m}^{3} \mathrm{~s}^{-1}$, conductivity is more variable and in some cases increases with discharge. The hypothesis considered here is that, as observed in other Amazonian contexts (Markewitz et al. 2001), the highest concentration during the rainy period (NovemberMay), when discharge is higher than $1,800 \mathrm{~m}^{3} \mathrm{~s}^{-1}$, can reflect inputs from the mobilization of elements by surface runoff from the upper layer of the soils. Such a contribution might vary in the Andes from one rain event to another due to the spatial and temporal rainfall heterogeneity (Roche et al. 1990; Guyot et al. 1993). During the dry period, the variability in concentration would be mainly controlled by the dilution effect associated with groundwater inputs. Downstream, on the Madeira basins at the PVE and FAZ stations, the conductivity is less variable for a given discharge range. The conductivity decreases with discharge, but $b$ value remains high $(b \sim-0.2)$ and the flux variability is therefore mainly controlled by discharge variability. This dilution effect has been previously reported by Roche and Fernandez Jauregui (1988) in plain basins of the Madeira.

In the basins of the shields (SER, CAI and ITA), the conductivity remains relatively constant (with $b$ value higher than -0.1 and lower than 0.1 ) in response to the hydrological cycle.

The $b$ values for $\mathrm{Ca}, \mathrm{Mg}, \mathrm{SO}_{4}$ and $\mathrm{HCO}_{3}$ are higher than -0.5 but are generally lower than 0 . For $\mathrm{Ca}, \mathrm{Mg}, \mathrm{HCO}_{3}$ and TDS, the Solimões stations exhibit generally higher $b$ values than the Madeira stations, as previously shown by Sanchez et al. (2015). This implies that the Solimões basins are more responsive to rainfall events in term of solute delivery than the Madeira basins, which tend to dilute to a limited extent. $\mathrm{Cl}$ and $\mathrm{Na}$ exhibit very variable $b$ values ranging from $-0.78 \pm 0.09$ to $0.04 \pm 0.06$, and the lowest $b$ values are generally recorded at some Napo stations, Maranon-Ucayali stations and downstream Solimões and Amazon stations (TAB, MAN and $\mathrm{OBI}$ ), whereas $b$ values closer to 0 are recorded in the plain (LAB) and in the tributaries in the shields (CAI and ITA). The Napo River exhibits an overall decrease of $b$ from the Andean stations to the foreland station (BEL). This implies that the foreland area of this basin contributes more to diluting the Andean inputs than it contributes to solute inputs. Among the solutes, the $b$ values of $\mathrm{Si}$ and $\mathrm{K}$ are close to 0 in most cases. With the exception of $\mathrm{Cl}$ and $\mathrm{Na}$, these results imply that, at first order, discharge variability is the main factor controlling the variability of solute and TDS fluxes throughout the year.

These $C-Q$ regressions must be considered as indexes that allow characterizing the first-order relationship between the variability of solutes and their respective daily discharge using a large amount of data from 30 stations of the Amazon basin. In specific cases, these relationships are not significant (e.g. NYO station, Moquet et al. 2014b), and in other cases, other functional relationships can better explain the temporal variability in concentration. This is the case in particular when a significant hysteresis is observed. We illustrate this latter case through the description of hysteresis behaviour observed at the OBI station.

At the OBI station, the $C-Q$ regressions defined for conductivity and TDS concentration allow estimating the measured values with a mean average error of $\pm 8 \mu \mathrm{S} \mathrm{cm}^{-1}$ and $\pm 7.5 \mathrm{mg} \mathrm{L}^{-1}$, respectively. Nevertheless, examining closely the TDS and the conductivity as a function of discharge, a non-univocal $C-Q$ relationship is observed (Fig. 6a). The relationship between conductivity and discharge of the Amazon at the OBI station follows a clockwise hysteresis and concave curvature behaviour (' $\mathrm{C} 1$ ' type hysteresis of Evans and Davies 1998 classification) (Fig. 6a). The highest conductivity values $\left(>70 \mu \mathrm{S} \mathrm{cm}^{-1}\right)$ are recorded during the low water stage (November-December), whereas lower values are recorded during the high water stage (June-August period). For a given discharge value, higher conductivities associated with the increasing water stage (January-May) compared with the decreasing water stage (September-October) are recorded. Here, this absence of a univocal relationship between TDS and discharge is clearly due to a mass water mixing phenomenon that is the combined effect of (1) the contrast of the mean TDS concentration/conductivity between the three main tributaries (Negro, Solimões and Madeira Rivers) and (2) the lag of their relative discharge contribution over the course of the year. The monthly TDS flux at the OBI station corresponds to the sum of the inputs of the Solimões River at the MAN station, the Madeira River at the FAZ station and the Negro River at the CAI and SER stations within a range of $\pm 11 \%$ (relative difference between the monthly OBI fluxes and the upstream tributary fluxes) (Fig. 6b). Following this calculation, the Solimões controls 


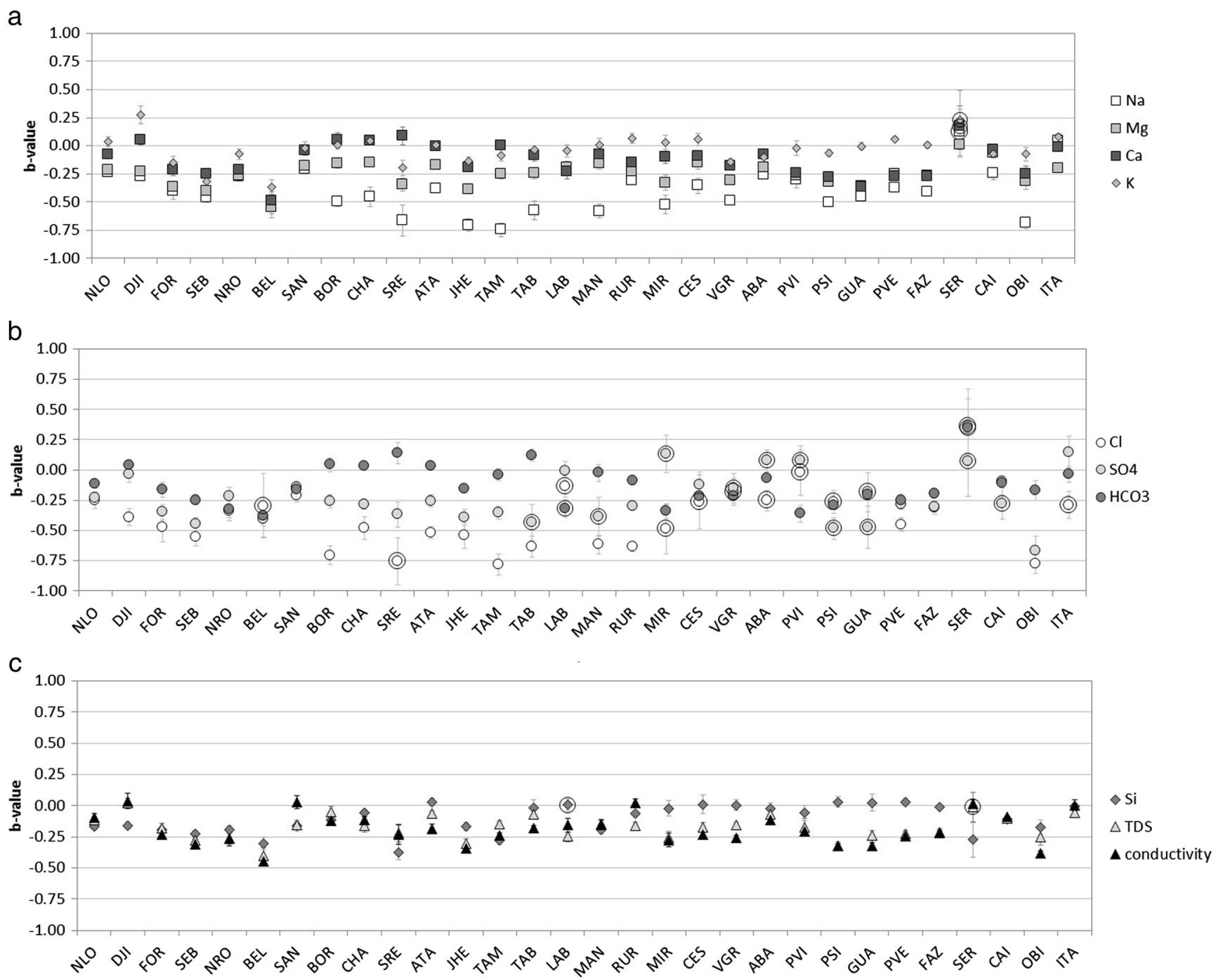

Fig. 4 Log- $\log$ slopes of concentration-discharge relationships $\left(\log \left(C_{\mathrm{i}}\right)=a+b \log \left(Q_{\mathrm{i}}\right)\right)$ for studied stations by site name for cations (a), anions (b), TDS, $\mathrm{Si}$ and conductivity (c). Error bars indicate \pm 1 standard error (SE). Large symbols indicate that the MAE of the $C-Q$ relationship is $>50 \%$

between 77 and $89 \%$ of the monthly TDS inputs in February and September, respectively. In contrast, the Madeira River controls between 8 and $22 \%$ of the TDS inputs in September and February, respectively. The Negro River inputs at the CAI and SER stations control less than $5 \%$ of the monthly TDS flux over the course of the year. The hysteresis behaviour is also explained by the variation in the relative discharge contribution of the Solimões, the Madeira and the Negro Rivers (Fig. 2). During the November-January period, when TDS concentration is at a maximum at the Óbidos station, the Solimões at the MAN station controls more than $60 \%$ of the Amazon discharge at the OBI station. During the February-June period, the relative contribution of the Solimões discharge decreases as the discharge of the Madeira continues to contribute more than $20 \%$ of the Amazon discharge. The TDS flux of the Solimões River is consequently partly diluted by that of the Madeira River. During the July-October period, the discharge inputs of the Negro River and the discharge produced by the remaining area between the Negro, Solimões and Madeira River stations and the OBI station are maximal and represent more than $30 \%$ of the Óbidos discharge. These highly diluted water inputs would consequently dilute the mineralized Solimões and Madeira River water inputs. To confirm this behaviour, we calculated the TDS concentration at the OBI station following Eq. 2:

$C_{\mathrm{OBI}}=\left(F_{\mathrm{MAN}}+F_{\mathrm{FAZ}}+F_{\mathrm{SER}}+F_{\mathrm{CAI}}\right) / Q_{\mathrm{OBI}}$

where $C_{\mathrm{OBI}}$ is the mean monthly concentration $\left(\mathrm{mg} \mathrm{L}^{-1}\right), F$ is the mean monthly flux at the MAN, FAZ, SER and CAI stations ( $\mathrm{mg} \mathrm{month}^{-1}$ ) and $Q_{\mathrm{OBI}}$ is the mean monthly discharge at the OBI station $\left(\mathrm{L} \mathrm{month}^{-1}\right)$.

This calculation reproduces the TDS concentration at the OBI station within a range of $\pm 6 \mathrm{mg} \mathrm{L}^{-1}$ (Fig. 6c). 

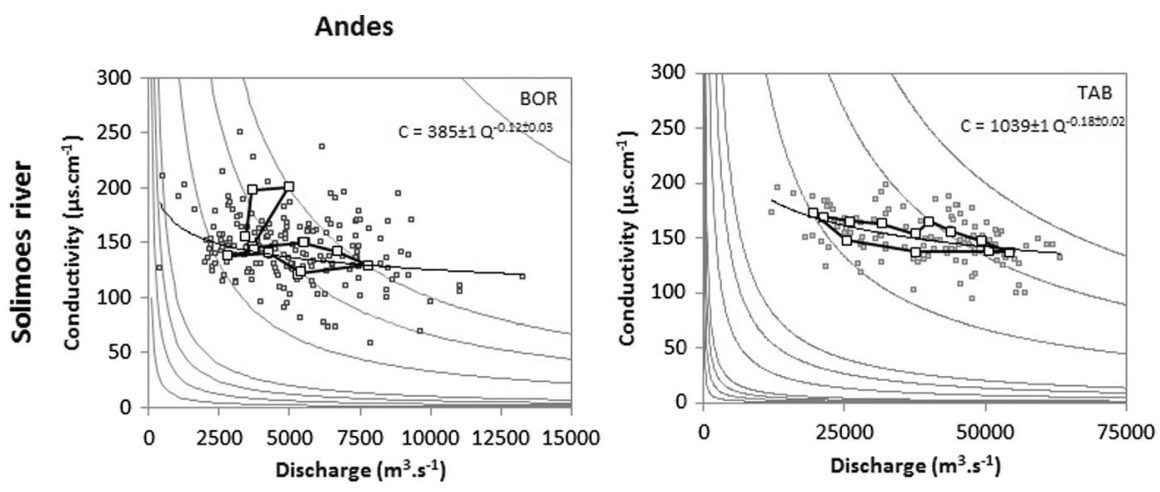

Plain
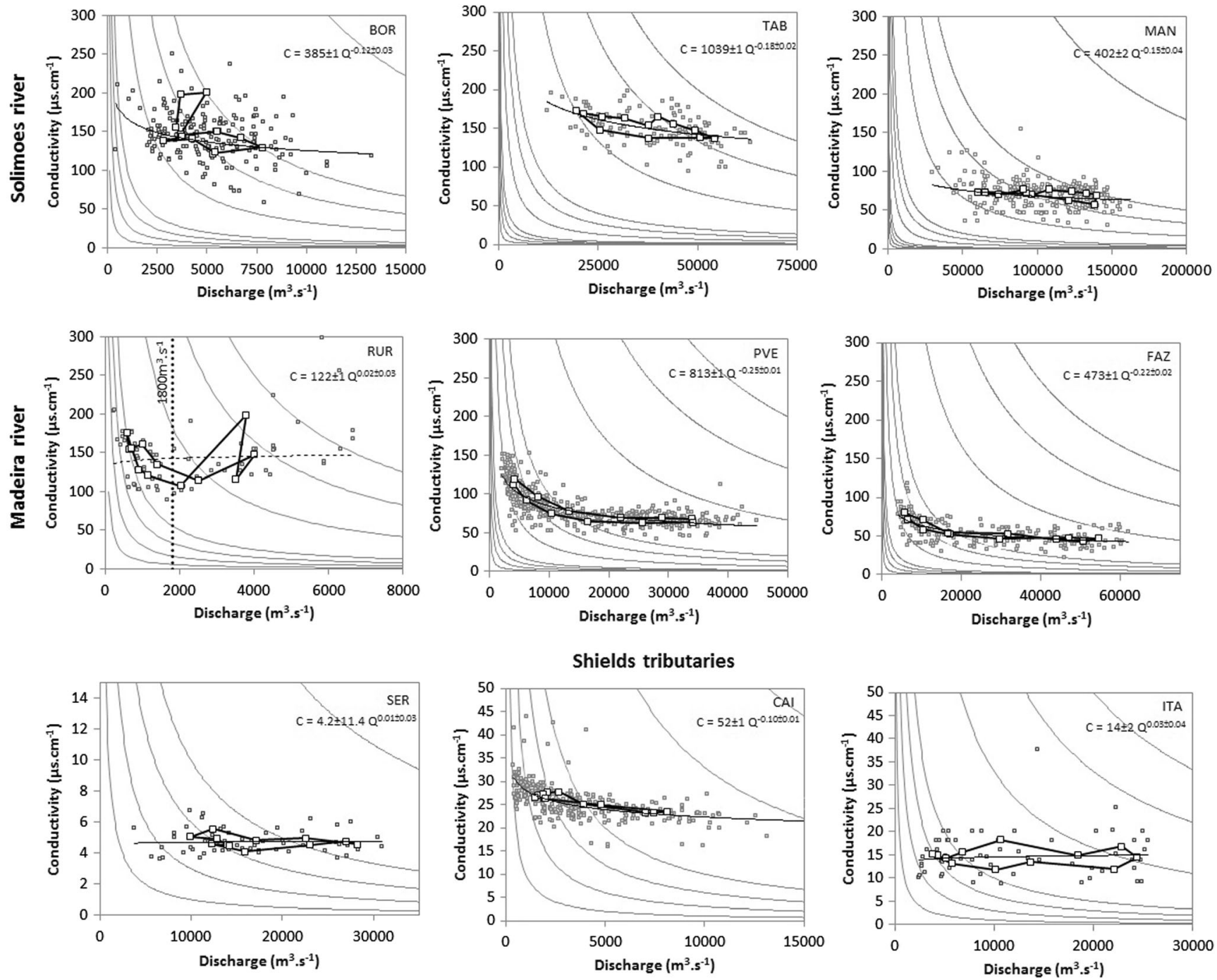

Fig. 5 Ten-day frequency conductivity measurements (small symbols) and monthly averages (large symbols and lines) plotted against discharge for nine selected gauging stations. Simple dilution curves (concentration variability of a constant flux) are added for reference

Not all individual solutes show hysteresis. As $\mathrm{Ca}$ and $\mathrm{HCO}_{3}$ are the main species contributing to the TDS content (Fig. 3), they control the hysteresis behaviour observed for TDS and conductivity and also individually show hysteresis (Fig. S1). Hysteresis phenomena are also observed for $\mathrm{Mg}$, $\mathrm{SO}_{4}$ and $\mathrm{K} . \mathrm{Cl}$ and $\mathrm{Na}$ exhibit dilution behaviour because these elements are mainly produced by the Solimões basin. Consequently, the Negro and Madeira Rivers mainly dilute these waters. Si exhibits a low variability in response to the hydrological cycle because of the low contrast in concentration between the contributing tributaries (Fig. S1). A slight hysteresis for $\mathrm{Ca}$ and $\mathrm{HCO}_{3}$ is observed upstream at the TAM, TAB and MAN stations (Solimões River), and a clear hysteresis is observed for $\mathrm{SO}_{4}$ at the $\mathrm{FAZ}$ station (Madeira River). The variability in the $\mathrm{Ca}, \mathrm{HCO}_{3}$ and TDS concentrations remains low and does not explain the observed hysteresis for these solutes at the OBI station. Indeed, considering a constant concentration of $\mathrm{Ca}, \mathrm{HCO}_{3}$ and TDS throughout the year (mean values in Table 3) at the upstream stations, we are able to reproduce the variability in concentration observed at the OBI station based on Eq. 2 (we considered a constant concentration and the monthly discharge at each station) with a maximum monthly error of $+9 \mathrm{mg} \mathrm{L}^{-1}$ for TDS (Fig. 6), $+48 \mu \mathrm{mol} \mathrm{L}^{-1}$ for $\mathrm{Ca}$ and $+88 \mu \mathrm{mol} \mathrm{L}^{-1}$ for $\mathrm{HCO}_{3}$. The $\mathrm{Si}$ and $\mathrm{K}$ concentrations remain relatively constant at the upstream stations. The high hysteresis of $\mathrm{SO}_{4}$ observed at the FAZ station explains a significant part of the $\mathrm{SO}_{4}$ variability observed at the OBI station. Indeed, considering a constant $\mathrm{SO}_{4}$ concentration upstream of the $\mathrm{OBI}$ station, the monthly $\mathrm{SO}_{4}$ concentration is reproduced with a maximal error of $16 \mu \mathrm{mol} \mathrm{L}{ }^{-1}$ in July. Nevertheless, $\mathrm{SO}_{4}$ contributes only to $4-9 \%$ of the Amazon TDS over the course of the year. In 


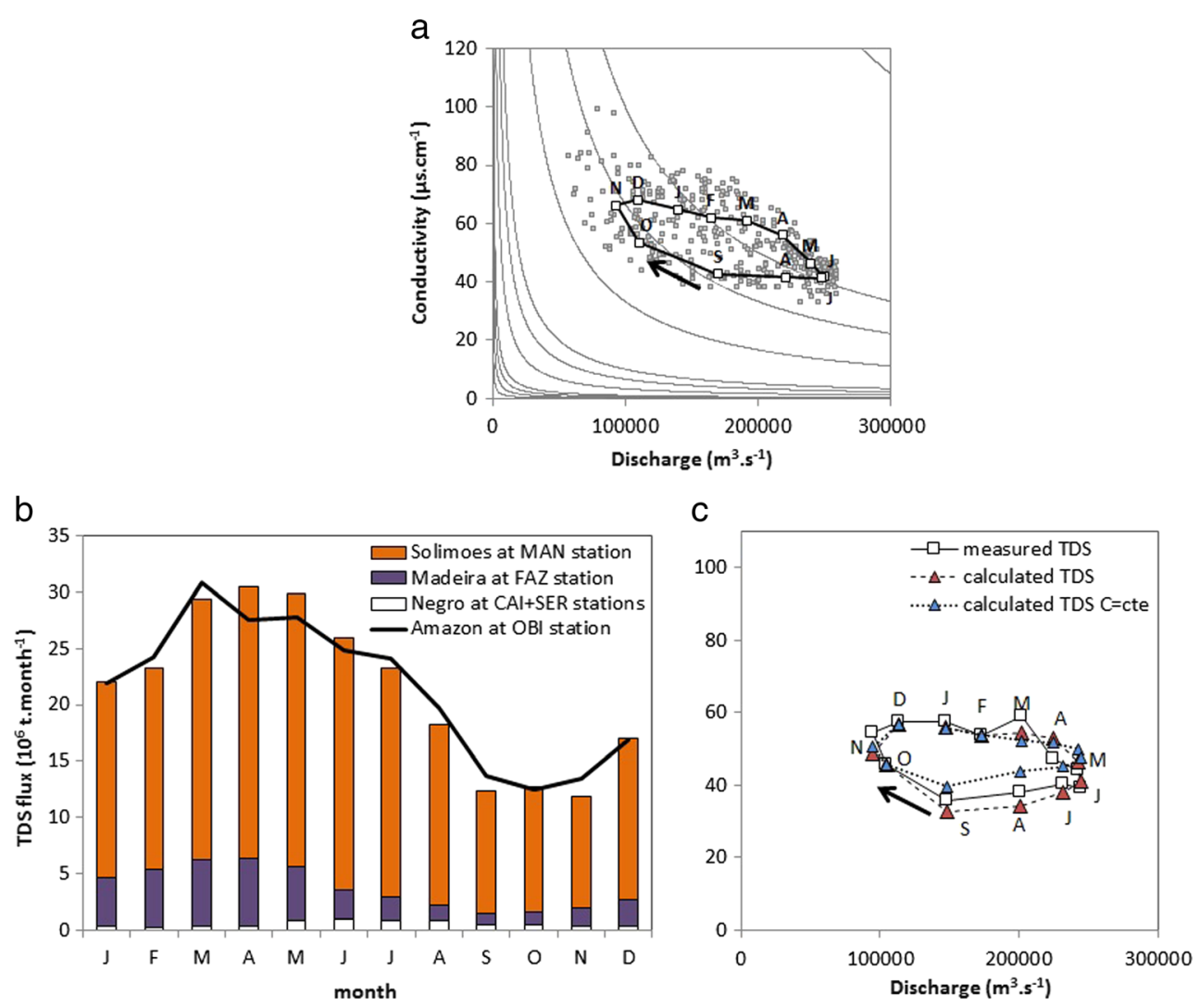

Fig. 6 a Ten-day frequency conductivity values (small symbols) and interannual monthly conductivity averages (large symbols and lines) at Óbidos as a function of discharge (September 1994 to December 2012 period). Simple dilution curves (concentration variability of a constant flux) are added for reference. b Comparison of the sum of the monthly TDS flux of the Solimões at the MAN station, Madeira at the FAZ station and Negro at the CAI and SER stations with the Amazon TDS flux at the

consequence, the dynamics of this solute do not contribute significantly to the observed TDS/conductivity hysteresis.

This result highlights the need for a monthly sampling frequency to accurately calculate the dissolved flux of the Amazon basin.

\section{Annual flux calculation}

The database allows us to estimate the solute fluxes from the different domains of the Amazon basin. The Amazon basin (Amazon flux at OBI + Tapajós Basin at ITA + Xingu basin at ALT) produced approximately $272( \pm 54) \times 10^{6} \mathrm{t} \mathrm{TDS} \mathrm{year}^{-1}$ during the period 2003-2012. Using out four calculation methods (Table S1) based on the same database, results range between 263 and $278 \times 10^{6}$ t TDS year ${ }^{-1}$ (Supplementary material S2).

The Andean tributaries (Napo, Marañon, Ucayali, Madre de Dios, Beni and Mamoré Rivers) contribute approximately $64 \%$ of the Amazon TDS flux for only $26 \%$ of the discharge and $25 \%$ of the basin area (Fig. 7). The central plain ( $37 \%$ of the basin area) and the shield tributaries (37\% of
OBI station (January 2003 to December 2012 period). c Comparison of the mean monthly TDS concentration at the OBI station, the calculated Amazon TDS using fluxes (sum of the monthly TDS flux at the MAN, FAZ, SER and CAI stations divided by the monthly discharge at the OBI station) and the calculated Amazon TDS considering constant TDS concentrations at the MAN, FAZ, SER and CAI stations as a function of the mean monthly discharge (January 2003 to December 2012 period) at OBI

the basin area) contribute approximately 25 and $11 \%$ of the TDS flux, respectively (Table 4 and Fig. 7). The MarañonUcayali basins largely dominate the Andean TDS fluxes. These basins contribute approximately $50 \%$ of the Amazon TDS flux for only $14 \%$ of the Amazon discharge and $13 \%$ of the Amazon basin area (Fig. 7). Nevertheless, this spatial flux distribution is not homogenous for all the elements (Table 4 and Fig. 7). The Marañon-Ucayali Rivers contribute $60-70 \%$ of the $\mathrm{Na}, \mathrm{Ca}$ and $\mathrm{HCO}_{3}$ exports of the Amazon. Approximately 21 and $9 \%$ of the Amazon $\mathrm{HCO}_{3}$ flux are produced by the central plain area and the tributaries in the shields, respectively, whereas $70 \%$ of this budget is produced by the Andean and foreland tributaries. $\mathrm{Cl}$ and $\mathrm{SO}_{4}$ are mainly produced by the Andean and foreland sub-basins (83 and $88 \%$ of the Amazon flux, respectively). Even if the Andean basins dominate the $\mathrm{Mg}$ flux, the contribution from the Solimões central plain and the shields is significant $(37 \%$ of the Amazon flux). In contrast with the other elements, the Amazon central plain and the shields are the main sources of $\mathrm{K}$ and Si (Table 4 and Fig. 7). 
Fig. 7 a Contribution of each sub-basin of the Amazon basin to the surface area, the discharge and the dissolved load production. $(\mathrm{TDS}=\mathrm{Ca}+\mathrm{Mg}+\mathrm{Na}+\mathrm{K}+\mathrm{Cl}+$ $\mathrm{SO}_{4}+\mathrm{HCO}_{3}+\mathrm{SiO}_{2}$ in mass unit). b Total flux of each major element from the Amazon a

$\square$ Napo
$\square$ Maranon
$\square$ Ucayali
$\square$ Madre de Dios
$\square$ Beni
$\square$ Mamore
$\square$ Solimoes-Amazon floodplain
$\square$ Guiana shield Tributaries (Negro River)
$\square$ Brazilian shield Tributaries (Lower
Madeira, Tapajos, Xingu)
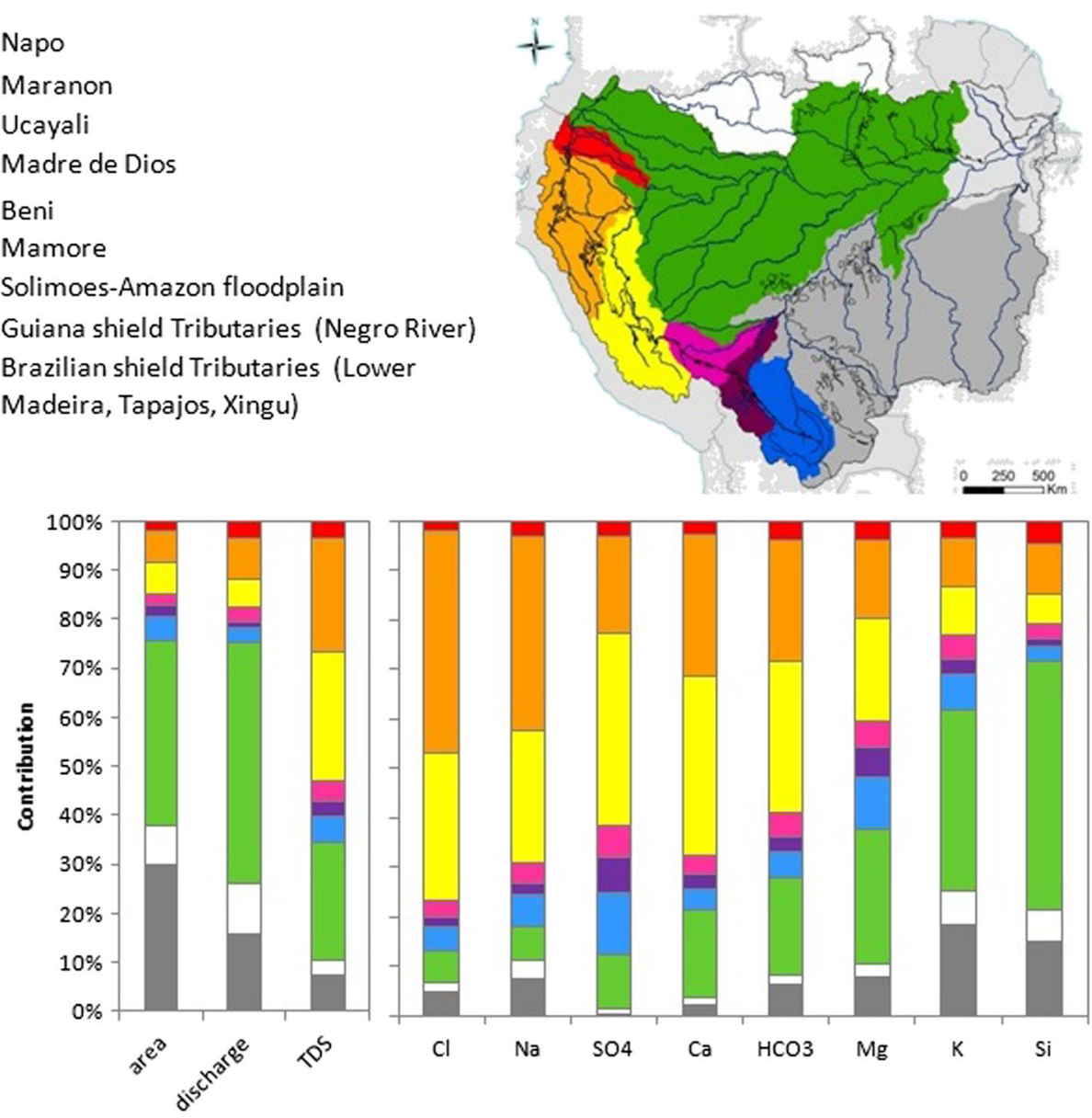

b

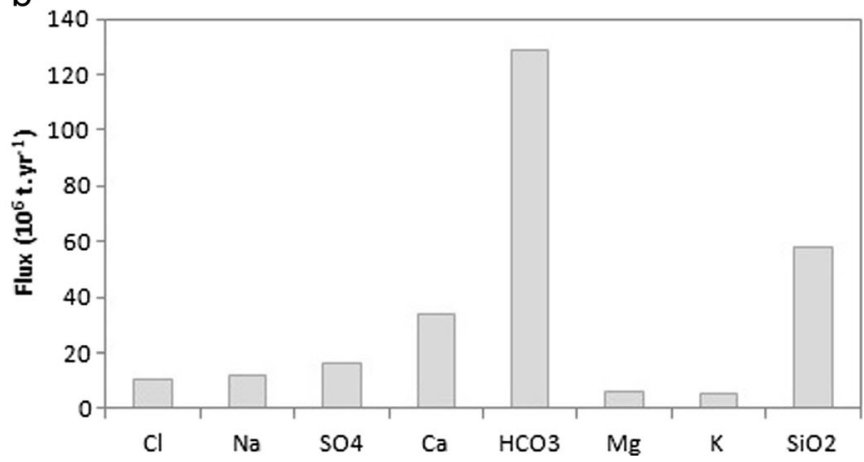

(Moquet et al. 2011). The remaining $\mathrm{Cl}, \mathrm{Na}$ and $\mathrm{SO}_{4}$ produced by the central plain and the shields are mainly derived from atmospheric inputs $\left(\mathrm{Cl}, \mathrm{Na}\right.$ and $\left.\mathrm{SO}_{4}\right)$, silicate weathering $(\mathrm{Na})$ and, in the shields, from pyrite oxidation $\left(\mathrm{SO}_{4}\right)$ as evaporite are nearly absent their (Stallard and Edmond 1983). However, in the Solimões Andean and foreland basins, these elements can be considered as proxies for evaporite dissolution.

After February 2009 (when anthropogenic inputs stopped), $b$ value is close to -1 for these elements controlled by evaporites inputs (Moquet et al. 2014b). This implies that the dissolved flux released by evaporite dissolution is relatively constant and insensitive to discharge variability, as also observed 
Table 4 Dissolved load flux calculation by geomorphological setting

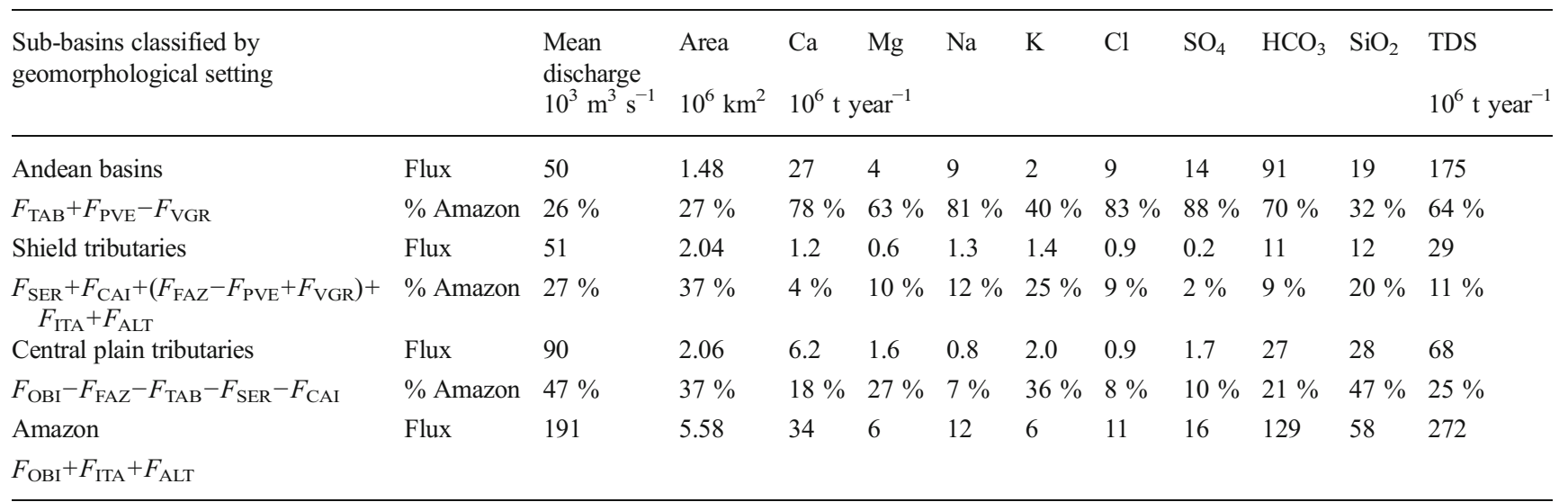

The formula used for the flux calculation is also reported

$F_{x}$ annual flux of the considered major element at gauging station $x$

in the Southern Andes (Leon and Pedrozo 2015). A possible mechanism is that these inputs can be associated either with a constant groundwater flux after interaction with diapir domes or with constant flux from local resurgences of deep water. These deep saline waters would then be diluted by surface water during hydrological cycle.

\section{Other sources}

For $\mathrm{Cl}, \mathrm{SO}_{4}$ and $\mathrm{Na}$ in all other basins and for all elements in all contexts, the $C-Q$ relationship is shallow $(-0.1>b>-0.5)$ or nearly chemostatic $(0.1>b>-0.1)$. This implies that dilute rainfall water does not act as a simple diluter. Low dilution and chemostatic $C-Q$ relationships are observed in catchments of diverse sizes $\left(10^{1}-10^{6} \mathrm{~km}^{2}\right)$ (e.g. Kirchner 2003; Godsey et al. 2009; Clow and Mast 2010; Maher 2011; Basu et al. 2011; Guan et al. 2011; Moon et al. 2014; Stallard and Herndon et al. 2015). These relationships are the result of hydrological (mixing reservoirs, mixing tributaries) or chemical (kinetic or thermodynamic equilibrium) processes (Clow and Mast 2010; Maher 2011; Eiriksdottir et al. 2013) that influence the way solutes are produced and exported by watersheds. It has been suggested that an important control of the chemostatic or nearly chemostatic $C-Q$ response of a hydrosystem is the residence time of water (Maher 2010, 2011; Maher and Druhan 2014; Li et al., 2014; Maher and Chamberlain 2014). A chemostatic behaviour in rivers would be observed when the water has sufficient time to reach equilibrium with minerals. Various models have been able to reproduce the chemostatic behaviour observed in most settings (e.g. Godsey et al. 2009; Jawitz and Mitchell 2011). Based on catchments in the Colorado Rocky Mountains, Clow and Mast (2010) indicated that cation exchange and seasonal precipitation and dissolution of amorphous or poorly crystalline aluminosilicates are important processes that regulate the concentration in a stream. At the scale of large rivers, the observed chemostatic behaviour can also be explained by the contribution of hydrological reservoirs and tributary inputs with different concentrations induced by different processes. The mix of these waters would result in a buffered signal with nearly constant concentration with increasing stream order (Creed et al. 2015).

For $\mathrm{Ca}, \mathrm{HCO}_{3}$ and TDS in the Andes, the chemostatic behaviour of the Maranon and Ucayali would therefore reflect more reactive mineralogy than that of the Napo and Madeira basins, where low dilution is observed (Figs. 4 and 5). This is consistent, at first order, with the fact that the carbonates, which are mainly restricted to the Maranon-Ucayali basins, are more reactive than silicates, which are the main sources of these elements in the Napo and the Upper Madeira (Moquet et al. 2011). Indeed, far from equilibrium, carbonates are highly reactive to weathering compared to silicate minerals (Lasaga and Berner 1998) and waters are able to rapidly reach equilibrium with respect to carbonate minerals.

In all Amazonian contexts, $\mathrm{K}$ and $\mathrm{Si}$ generally exhibit chemostatic behaviour. Godsey et al. (2009) observe the same phenomenon for $\mathrm{Si}$ in small catchments in the USA. They highlighted that the rates of reaction including these elements are very slow, implying that stream water should always be far from equilibrium with respect to the weathered material. The mechanism controlling chemostasis in this case may consequently be due to a ubiquitous source homogeneously distributed throughout the subsurface in the Amazon basin (clays or phytoliths for example) or to preferential contribution of the flushing of old water to the rivers.

\section{Hysteresis behaviour at the OBI station}

Previous studies on hysteresis of $C-Q$ relationships observed in rivers mainly focused on solid suspended matter 
(e.g. Wood 1977; Walling and Webb 1982; Richey et al. 1986; Meade 1994; Jansson 2002; Guyot et al. 2005; Martinez et al. 2009; Filizola et al. 2011; Armijos et al. 2013), but this behaviour remains less documented for solutes.

Hysteresis for solutes $C-Q$ relationships is generally observed during storm events (e.g. House and Warwick 1998; Bowes et al. 2005) and is more rarely reported at the scale of large basins (Coynel et al. 2005; Ollivier et al. 2006). Hysteresis trends for dissolved solid concentrations are induced by time lags between dissolved solid and water contributions of reservoirs or tributaries (e.g. Ollivier et al. 2006). These time lags arise when different dissolution kinetics occur in the reservoirs and/or when the water transit times between reservoirs are different (e.g. House and Warwick 1998; Rose 2003). Solid suspended matter in rivers can also be a significant source or sink of some dissolved elements and can control the concentrations of those elements (Bowes et al. 2005). This last case is especially observed for bioreactive solutes, like phosphorus (Bowes et al. 2005; O'Connor et al. 2011), dissolved organic nitrates and dissolved organic carbon (Edokpa et al. 2015).

Although, in the Amazon, the hysteresis behaviour between TSS concentrations and discharge at the OBI station is well established (e.g. Richey et al. 1986; Meade 1994; Filizola and Guyot 2009; Filizola et al. 2011; Martinez et al. 2009), it is less well characterized for TDS concentration (Tardy et al. 2005; Bustillo et al. 2010) and never with a high frequency conductivity allowing a precise characterization of the phenomena.

Both TDS and TSS hysteresis phenomena are clockwise, but their relative variability in response to the hydrological cycle is different (Fig. 8a, b). Indeed, the relative amplitude of TSS (9.8 to $255 \mathrm{mg} \mathrm{L}^{-1}$ ) is higher than that of conductivity ( 26 to $99 \mu \mathrm{S} \mathrm{cm}^{-1}$ ), whereas the daily discharge (over the days of sampling) varies from 52,500 to $259,600 \mathrm{~m}^{3} \mathrm{~s}^{-1}$. In response to the hydrological cycle, during the decreasing and low water stages, high variability in conductivity is recorded when TSS is almost constant and minimal. During the increasing water stage, the TDS concentration remains high because of the high input of the Solimões River, whereas TSS increases. In the March-April-May (MAM) periods, during the second half of the increasing water stage, TDS and TSS decrease together because of the dilution effect of the Negro inputs for both TSS and TDS concentrations (Fig. 8c).

TSS and TDS concentrations respond to different mobilization processes (as generally observed in most rivers; e.g. Négrel et al. 2007; Sondag et al. 2010), and they are not produced in equivalent proportion by the Amazon tributaries. In the Amazon, the TSS dynamics has been explained by the combination of various processes such as the 'depletion' or 'exhaustion' effect (e.g. Meade 1994), the lag in time of tributary inputs (Filizola and Guyot 2009; Filizola et al. 2011) and the backwater effect (Meade et al. 1991; Espinoza et al. 2013), but this behaviour remains debated.

In contrast with TSS, the hysteresis observed for TDS is explained by a simple mixing model. The three main tributaries (Solimões, Madeira and Rio Negro) show different average TDS concentrations with low fluctuation during the hydrological cycle. Consequently, hysteresis of TDS concentration at $\mathrm{OBI}$ arises mainly because of offsets between the contributions of the main tributaries during the hydrologic cycle (Fig. 6).

\section{Origin of the dissolved load throughout the Amazon basin}

\section{The Andean inputs}

The Andean (including foreland) basins produce approximately $172 \times 10^{6}$ t TDS year ${ }^{-1}$ and contribute approximately $64 \%$ of the TDS of the Amazon basin (Figs. 7 and 9). Even though the Andean TDS contribution to the Amazon exports was identified early on as the main solute source of the Amazon River (Gibbs 1967a, b; Stallard and Edmond 1983), estimates of its relative contribution to TDS and solutes fluxes have rarely been reported (McClain and Naiman 2008; Mortatti and Probst 2003). Based on eight samples along the hydrological cycle on the main tributaries of the SolimõesAmazon River, Mortatti and Probst (2003) estimated that the Andean basins contributed up to $80 \%$ (201 t TDS year ${ }^{-1}$ ) of the Amazon TDS production. Our estimates are lower than these estimates. The difference can be attributed to both differences in sampling frequency and to the spatial distribution of the sampled stations. The high sampling frequency and the distribution of the SO-HYBAM framework stations allow for precise quantification of TDS and solute fluxes and of the relative contribution of the Andes and central plain.

The TDS specific flux from the Andes (118x $10^{3} \mathrm{t} \mathrm{km}^{-2}$ year $\left.^{-1}\right)$ is larger than that from the plain $(33 \times$ $10^{3} \mathrm{t} \mathrm{km}^{-2}$ year $\left.^{-1}\right)$ and the shields $\left(14 \times 10^{3} \mathrm{t} \mathrm{km}^{-2}\right.$ year $\left.^{-1}\right)$ for similar runoff values $\left(1,070,1,375\right.$ and $790 \mathrm{~mm} \mathrm{year}^{-1}$ for the Andes, central plain and shields, respectively) (Fig. 9b). Specific fluxes are a function of concentration and of runoff. We previously showed that the temporal variability of most of the solute fluxes is mainly controlled by discharge variability. Nevertheless, as the mean runoff across these three geomorphological domains is similar, the Andes-sedimentary areas-shield TDS-specific flux (and flux) gradient observed throughout the basin is controlled by the contrast in TDS concentration values rather than by runoff (and discharge) variability. This observation shows that the total weathering flux of the Amazon is primarily controlled by the geomorphological/geological setting rather than by the spatial variability of the water supply (Figs. 7 and 9). This result confirms the high sensitivity of the Andean environment to weathering processes compared with sedimentary areas and 
Fig. 8 Ten-day frequency conductivity values (a) and TSS concentration (b) as a function of discharge at the Óbidos station (September 1994 to December 2012 period). c Conductivity as a function of TSS concentration
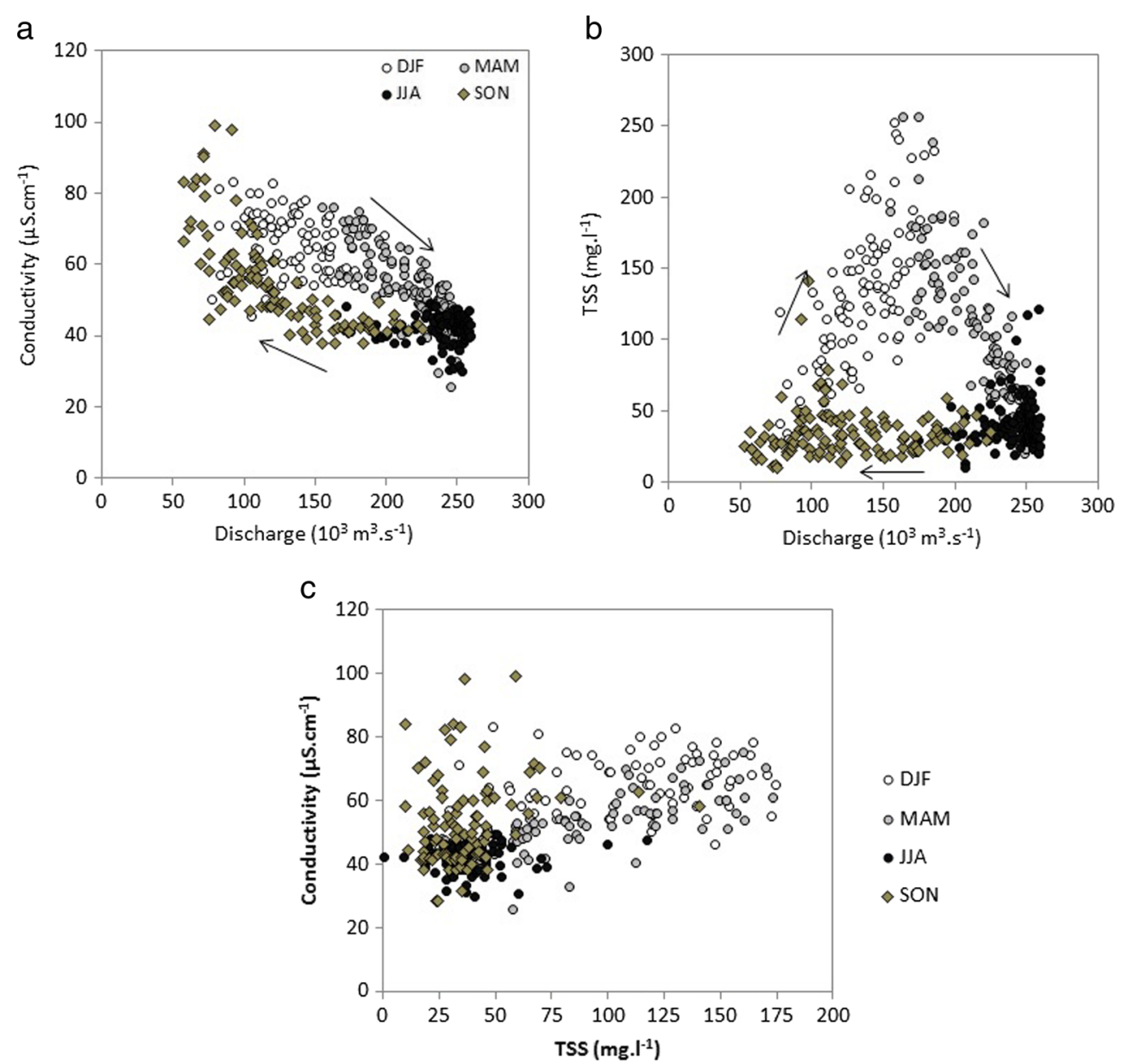

shields. Indeed, in orogenic areas such as the Andes, high slopes and physical erosion favour the contact between minerals sensitive to weathering processes (carbonates, evaporites and primary silicate minerals) and water (Stallard 1985; Raymo and Ruddiman 1992; Dupré et al. 2003; Milliman and Farnsworth 2011). Furthermore, the TDS $b$ value decreases from Andean basins to floodplain areas (Fig. 5). Torres et al. (2015) observed also this phenomenon for solutes derived from silicate weathering in the Andean and Andean foreland of the Madre de Dios basin (Madeira River). They explained this observation by the topography and/or erosional regime differences between Andes and Andean foreland contexts. In particular, in mountains, the high erosion would favour the abundance of reactive mineral and the fluid transit time in fractured bedrocks would be longer than in plain, while foreland floodplain is composed of thick soils depleted in reactive minerals and, possibly, shorter fluid transit time.

\section{Role of the plains in the Amazon weathering budget}

The central plain area is currently active in terms of the TDS, $\mathrm{HCO}_{3}, \mathrm{Ca}, \mathrm{Mg}, \mathrm{K}$ and $\mathrm{Si}$ production of the Amazon basin (Fig. 7). Because of the absence of evaporites and carbonates, there silicate weathering and atmospheric inputs are the main sources of dissolved load in this area. The atmospheric inputs do not significantly influence the $\mathrm{HCO}_{3}$ and $\mathrm{Si}$ of rivers (Berner and Berner 1987; Stallard and Edmond 1983), and with the exception of the Negro River for $\mathrm{Mg}$ (Gaillardet et al. 1997), they influence less than $10 \%$ of the $\mathrm{Ca}, \mathrm{Mg}$ and K production (Gaillardet et al. 1997; Stallard and Edmond 1983). These elements are consequently released to the river from silicates directly by weathering processes $(\mathrm{Ca}, \mathrm{Mg}$, $\mathrm{HCO}_{3}, \mathrm{~K}$ and $\mathrm{Si}$ ) or indirectly through plant uptake and decay ( $\mathrm{K}$ and $\mathrm{Si}$ ). This implies that the central plain area is currently active in terms of silicate weathering and has a significant influence on the production of dissolved load in the Amazon basin. This is well illustrated by the budget of $\mathrm{HCO}_{3}$. In the Andean and foreland area, 75 (61-83)\% of the annual $\mathrm{HCO}_{3}$ flux derives from carbonate weathering (Moquet et al. 2011). Because the sub-basins of the central plain and shields are mainly underlain by silicate lithology and because rainfall inputs are negligible for $\mathrm{HCO}_{3}$ production in rivers, the $\mathrm{HCO}_{3}$ produced in this area is mainly derived from $\mathrm{CO}_{2}$ consumption associated with silicate weathering processes $\left(\mathrm{CO}_{2}\right.$ sil). Thus, the Andean sub-basins, the central plain sub-basins and the shield subbasins are, respectively, responsible for approximately $41 \%$ 


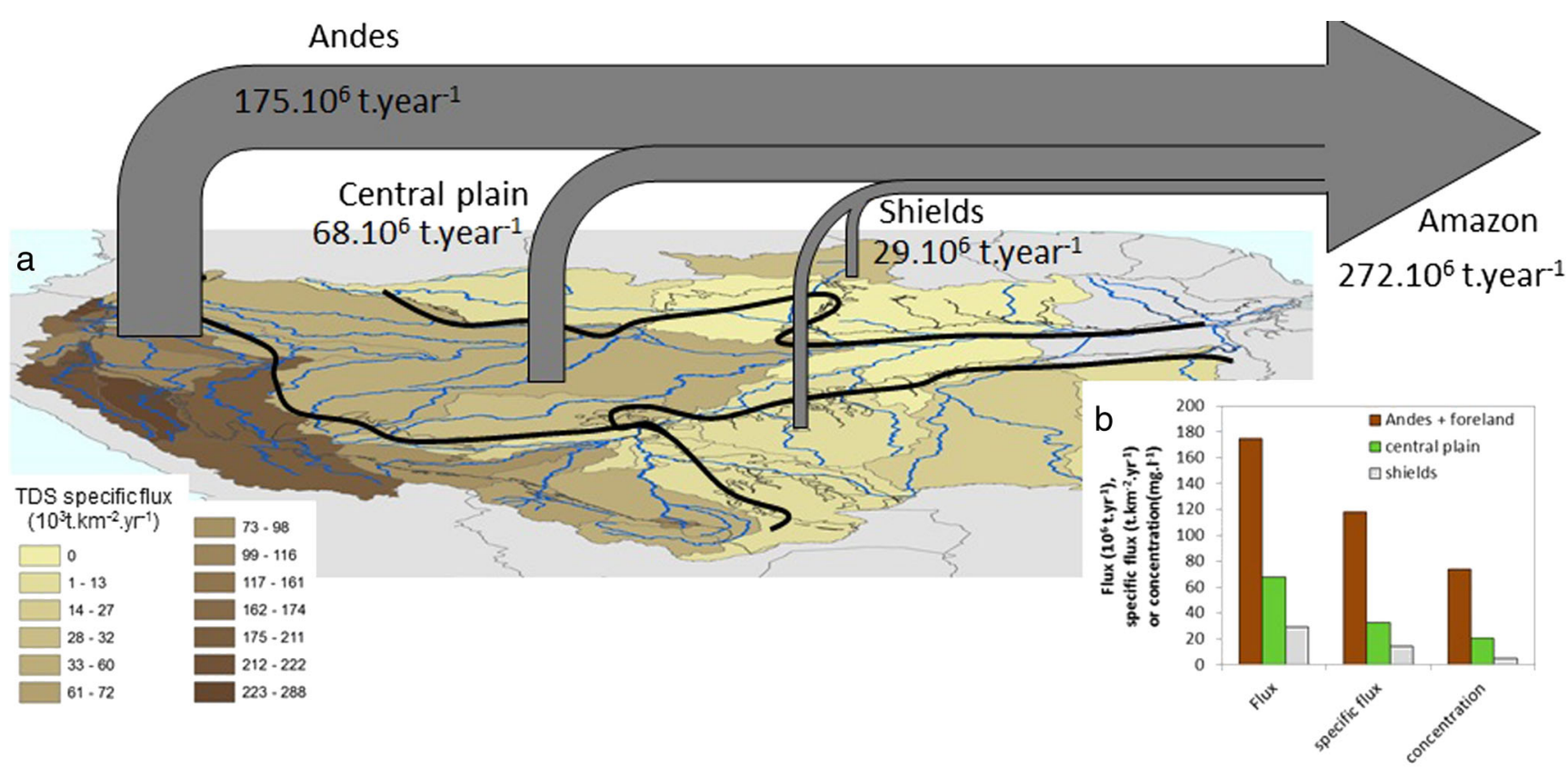

Fig. 9 a Specific flux of the dissolved load in the Amazon basin and TDS flux budget as a function of the main geomorphological contexts. b TDS flux, specific flux and mean concentration for the Andes, central plain and shields

(33-45), $41 \%(33-45)$ and $18 \%$ of the $\mathrm{HCO}_{3}$ flux derived from silicate weathering $\left(\mathrm{HCO}_{3}\right.$ sil) (or $\mathrm{CO}_{2}$ sil consumption). Following this calculation, the relative contribution of Andean $\mathrm{CO}_{2}$ sil consumption appears much lower than previous estimates (Mortatti and Probst 2003; Moquet et al. 2011). Nevertheless, this first-order estimate needs to be confirmed by further mass balance calculations allowing discrimination of the solute sources (atmospheric, evaporites, silicates, carbonates, anthropogenic inputs) (e.g. Gaillardet et al. 1997, 1999; Moon et al. 2014).

Our number shows that silicate weathering processes occurring in the sedimentary areas of an active mountain range can be significant at the scale of the basin, as shown by previous studies in the Amazon basin (Moquet et al. 2011; Bouchez et al. 2012, 2014) and the Brahmaputra basin (Galy and FranceLanord 1999; Lupker et al. 2012). The weathering budgets of these sedimentary area need to be taken into account for longterm carbon cycle modelling to estimate the long-term $\mathrm{CO}_{2}$ variability and the links between orogenesis, climates and chemical-physical erosion processes (e.g. GEOCARB, Berner and Kothavala 2001; COPSE, Mills et al. 2014; WITCH, Godderis et al. 2006; CIDRE, Carretier et al. 2014).

\section{The shields}

The shields rivers exhibit both the lowest TDS concentrations and the lowest TDS-specific fluxes observed of the studied stations (Fig. 9b). This observation is consistent with the previous observations of Stallard and Edmond (1983) and Gaillardet et al. (1997). Indeed, the formation of thick tropical soils would protect the bedrock from chemical weathering (Stallard 1985). This effect is particularly marked in the Upper Negro basin (SER station), where very low TDS concentrations are recorded $\left(\sim 6 \mathrm{mg} \mathrm{L}^{-1}\right)$ in comparison with the three other tributaries in the shields (the Branco, Tapajos and Xingu Rivers) (Table 3). The high runoff received by the upper Negro River compensates partially for the low concentration making TDS specific fluxes relatively high. Indeed, the TDS specific flux delivered by this area $\left(\sim 13 \times 10^{3} \mathrm{t} \mathrm{km}^{-2}\right.$ year $\left.^{-1}\right)$ is similar with the TDS specific flux measured in the Tapajos $(19 \times$ $10^{3} \mathrm{~km}^{-2}$ year ${ }^{-1}$ ) and Xingu Rivers ( $13 \times$ $10^{3} \mathrm{t} \mathrm{km}^{-2}$ year $^{-1}$ ) but is low compared with that of the Branco River $\left(31 \times 10^{3} \mathrm{~km}^{-2}\right.$ year $\left.^{-1}\right)$.

The Upper Negro (SER station) is characterized by podzols/ arenosols (more than $40 \%$ of the area; Dijkshoorn et al. 2005), which are mainly composed of quartz and have low sensitivity to weathering processes. In contrast, podzol/arenosol formations represent less than $3 \%$ of the surface of the other shield basins. Even if the deep soils of the area are known to be poor in mobile elements (Stallard and Edmond 1983, 1987), these soils are currently submitted to weathering processes and are still able to produce dissolved mobile elements. Indeed, due to their surface area and their contribution of discharge to the Amazon, the shields contribute significantly to the TDS production ( $11 \%$ of the Amazon flux), especially for Si and $\mathrm{K}$ production (20 and $25 \%$ of the Amazon flux, respectively). This observation highlights that the main parts of the shield areas have a low impact on the total weathering budget of the Amazon basin, although they are chemically active environments. 


\section{Annual Amazon dissolved load export to the oceans}

The Amazon basin (Amazon flux at OBI + Tapajós Basin at ITA + Xingu basin at ALT) produced approximately $272 \times 10^{6}$ t TDS year $^{-1}$ during the monitored period of 2003-2012 (Fig. 9). This value is close to previous estimates ranging from 251 to $292 \times 10^{6} \mathrm{t} \mathrm{TDS} \mathrm{year}^{-1}$ (Gibbs 1972; Berner and Berner 1987; Gaillardet et al. 1997, 1999; Mortatti and Probst 2003; Milliman and Farnsworth 2011; Sanchez et al. 2015). The flux for each element is also generally commensurate with the estimates of Gibbs (1972) and Mortatti and Probst (2003). The Amazon TDS solute production is dominated by $\mathrm{HCO}_{3}$, Si and $\mathrm{Ca}$, which represent 48,21 and $12 \%$ of the TDS, respectively (mass unit). Using the annually exported TSS $\left(600-800 \times 10^{6}\right.$ t year $^{-1}$; Guyot et al. 2005; Martinez et al. 2009; Filizola et al. 2011), the TDS flux corresponds to 25$31 \%$ of the total solid material carried by the Amazon River.

Using the Berner and Berner (1987) and Milliman and Farnsworth (2011) estimates of global continental TDS exportations $\left(3,843 \times 10^{6}\right.$ and $3,800 \times 10^{6} \mathrm{t} \mathrm{TDS} \mathrm{year}^{-1}$, respectively), the Amazon River contributes approximately $7 \%$ of the total dissolved load exported to the oceans. As highlighted by these authors, the Amazon River ranks as the most important basin in terms of dissolved load flux before the Changjiang (180 t TDS year $^{-1}$; Milliman and Farnsworth 2011) and has a dissolved yield (49 t TDS km$~^{-2}$ year $^{-1}$ ) similar with the world average ( 40 t TDS km ${ }^{-2}$ year $^{-1}$; Milliman and Farnsworth 2011). Individually, the Solimões, the Madeira and the rivers of the shields (Negro + Tapajós + Xingu) contribute up to $5.6 \%\left(214 \mathrm{t} \mathrm{TDS}_{\mathrm{Tear}}^{-1}\right), 1.0 \%$ (39 $\mathrm{t}$ TDS year $\left.{ }^{-1}\right)$ and $0.6 \%\left(22 \mathrm{t} \mathrm{TDS}\right.$ year $\left.^{-1}\right)$ of the global TDS flux, respectively. The Solimões itself is the first world basin in terms of the flux of river dissolved load. Following the hierarchy of 62 largest rivers of Gaillardet et al. (1999), the TDS flux of the Madeira River is similar with that of the Rhine (18th position), and the TDS fluxes delivered by the tributaries from the shields are together commensurate with those of the Don and Nelson River TDS fluxes (26th and 27th positions, respectively). The Solimões exhibits higher TDS specific flux values (97 t TDS km${ }^{-2}$ year $^{-1}$ ) than the global average and is similar with that of the Ganges Brahmaputra basin (which ranges as the third highest dissolved load of world rivers; Milliman and Farnsworth 2011), whereas the Madeira and the basins of the shields exhibit lower values than the world average (29 and $17 \mathrm{t} \mathrm{TDS} \mathrm{km}^{-2}$ year $^{-1}$, respectively). The $\mathrm{Ca}, \mathrm{Mg}, \mathrm{Na}$, $\mathrm{Cl}, \mathrm{SO}_{4}$ and $\mathrm{HCO}_{3}$ carried by the Amazon River to the oceans correspond to $5-8 \%$ of the world riverine fluxes, and the dissolved $\mathrm{Si}$ and $\mathrm{K}$ exports correspond to $10-12 \%$.

In the 2003-2012 period, only the $\mathrm{Cl}$ concentration appears to show a slight decrease between the period before and after February 2009 due to the decrease in contamination by oil extraction activities identified throughout the northern foreland (Tigre River at NYO) (Moquet et al. 2014b). The other elements do not show a significant interannual trend during the 10 years of monitoring at the Óbidos station.

\section{Potential effects of further climate changes}

During the last decades, the Amazon basin has been affected by climate changes in term of both the annual distribution of rainfall and increasing frequency of extreme events (Espinoza et al. 2009b; Lavado Casimiro et al. 2012). From global and regional climate models, climate projections predict that these trends will intensify in the future (IPCC report: Magrin et al. 2014). Projections reported by the IPCC (Magrin et al. 2014) agree that the basin will experience a significant increase in temperature. The projections for rainfall are affected by large uncertainties, but some general trends can be extracted on a regional scale. The northwestern part of the basin would experience higher precipitation, whereas central, southern and eastern Amazonia would be subjected to drier conditions (Giorgi and Diffenbaugh 2008; Bombardi and Carvalho 2009; Marengo et al. 2011; Magrin et al. 2014). Increases in the frequency and intensity of extreme events would accompany these general trends. Following these scenarios, if the observed $C-Q$ relationships at the scale of the hydrological year are valid for decadal evolution of discharge, the Amazon TDS fluxes would increase in the future because the main source of TDS is located in the northwestern part of the basin. In particular, the dissolved fluxes of the Amazon mainly associated with carbonate weathering in the Marañon and Ucayali basins would increase proportionally to the discharge, whereas the Madeira TDS fluxes would decrease. $\mathrm{Cl}$ and $\mathrm{Na}$ fluxes, controlled by evaporite inputs, would not be affected by projected climate changes. $\mathrm{Si}$ and $\mathrm{K}$ fluxes would vary proportionally with the mean rainfall variation of the Amazon basin. As a perspective and as performed by Von Blanckenburg et al. (2015) for the Last Glacial Maximum based on Maher and Chamberlain (2014) $C-Q$ model, further combination of derived $C-Q$ relationships with climate model output projections of Amazon river discharge (and its tributaries) would allow to assess future changes in flux due to the anthropogenically altered climate state.

Nevertheless, these predictions assume that the $C-Q$ relationships are stationary through time. However, weathering rates depend not only on water availability but also on a number of other parameters such as lithology, temperature, erosion rates, abundance of organic acids and vegetation (Goudie and Viles 2012 and references within). Moreover, it is likely that the $C-Q$ relationships determined for a given range of $Q$ are not stable for extreme conditions (Maher 2010). Further studies on small basins and on basins undergoing extreme climatic conditions need to be performed to better constrain these laws, to model chemical weathering processes and to better predict the future evolution of dissolved matter exportation from the Amazon basin. 


\section{Conclusion}

In the period 2003-2012, the Amazon basin exported an average of $272 \times 10^{6} \mathrm{t}^{\text {year }}{ }^{-1}$ of dissolved load, which corresponds to nearly $7 \%$ of the TDS flux annually exported from the continents to the oceans. The Amazon TDS exports are mainly composed of $\mathrm{HCO}_{3}, \mathrm{Si}$ and $\mathrm{Ca}$. $\mathrm{Ca}$ and $\mathrm{HCO}_{3}$ are mainly produced by carbonate weathering in the Andean basins and especially in the Marañon and Ucayali basins (representing approximately $50 \%$ of their fluxes), whereas Si production is mainly controlled by the spatial distribution of rainfall throughout the basin. A TDS concentration gradient is observed according to the following geomorphologic hierarchy: Andean basins $>$ sedimentary areas $>$ nonpodzolic shields $>$ podzolic shields. Due to its surface and its relative contribution to the Amazon, the water flux from the central plain significantly contributes to the dissolved production of the basin, with an export of approximately $25 \%$ of the total TDS flux. This result confirms that sedimentary areas are currently undergoing weathering processes. Further analysis needs to be performed to accurately discriminate the TDS sources.

Over the main Amazon tributaries, the variability of TDS fluxes is mainly controlled by discharge variability in response to the hydrological cycle. Evaporite dissolution produces a nearly constant flux throughout the year, whereas the TDS fluxes released by other sources (carbonate weathering, silicate weathering, biosphere and atmospheric inputs) are mainly controlled by variability in discharge. For the first time, the hysteresis behaviour observed for TDS (conductivity) at the Óbidos station is described. This phenomenon is mainly explained by the time lag in discharge seasonality of the three main tributaries (Solimões, Madeira and Negro), which have contrasted TDS concentrations. If the $C-Q$ relationships determined throughout the basin remain stable, further changes in rainfall distribution and intensity would consequently have a direct impact on the variability of TDS flux. In particular, an increase in rainfall over the western and northwestern subbasins underlain by carbonates would increase the exportation of $\mathrm{Ca}$ and $\mathrm{HCO}_{3}$, whereas the dissolved $\mathrm{Si}$ exportation would be nearly proportionally affected by the changes occurring over the Amazon basin surface. Nevertheless, the main processes controlling the $C-Q$ relationships of solutes throughout the basin are not identified. Further studies are still required to identify the main physico-chemical processes controlling these empirical laws, to better constrain their limitations and to quantify the effect of extreme events on these solute export budgets.

Acknowledgments We especially thank Daniel Ibarra (Stanford University) for his constructive recommendations under the review process. We also especially thank Dr. Julien Bouchez (CNRS-IPGP) for insightful discussions and his help to improve the manuscript. This work was funded by the French Institut de Recherche pour le Développement (IRD) and the French Institut des Sciences de l'Univers (INSU) through the SO-HYBAM Observatory. We especially thank Pascal Fraizy, Philippe Vauchel, William Santini, Elisa Armijos, Francis Sondag, Nore Arevalo, the Servicio Nacional de Meteorología e Hidrología-Lima, Peru and La Paz, Bolivia (SENAMHI), the Instituto Nacional de Meteorología e Hidrología-Quito, Ecuador (INAMHI), Agência Nacional de Águas-Brasília, Brazil (ANA), the Universidad Nacional Agraria de La Molina - Lima, Peru (UNALM), the Universidad Mayor de San Andres - La Paz, Bolivia (UMSA), Universidade de BrasíliaBrazil (UNB), Universidade do Estado de Amazonas-Manaus, Brazil (UEA) and all members of the SO-HYBAM (Hydrogeodynamics of the Amazon basin), for providing hydrological and water chemistry data.

\section{References}

Armijos E, Crave A, Vauchel P et al (2013a) Suspended sediment dynamic in the Amazon River of Peru. J S Am Earth Sci 44:75-84

Armijos E, Laraque A, Barba S et al (2013b) Suspended sediments and dissolved yields from the Andean basins of Ecuador. Hydrol Process 58:1478-1494

Aufdenkampe A, Mayorga E, Hedges JI et al (2007) Organic matter in the Peruvian headwaters of the Amazon: compositional evolution from the Andes to the lowland Amazon mainstem. Org Geochem 38:337-364

Baby P, Guyot JL, Hérail G (2009) Tectonic control of erosion and sedimentation in the Amazon Basin of Bolivia. Hydrol Process 23: 3225-3229

Basu NB, Thompson SE, Rao PS (2011) Hydrologic and biogeochemical functioning of intensively managed catchments: a synthesis of topdown analyses. Water Resources Research 47:W00J15

Beaulieu E, Goddéris Y, Labat D et al (2011) Modeling water-rock interaction in the Mackenzie basin: competition between sulfuric and carbonic acids. EPSL 289:114-123

Benavides V (1968) Saline deposits of South America. Geol Soc Am Spec Pap 88:249-290

Berner EK, Berner RA (1987) The global water cycle: geochemistry and environment. Englewood Cliffs, New Jersey

Berner RA, Kothavala (2001) GEOCARB III: a revised model of atmospheric CO2 over phanerozoic time. Am J Sci 301:182-204

Bombardi RJ, Carvalho LMV (2009) IPCC global coupled model simulations of the South America monsoon system. Clim Dyn 33:893-916

Bouchez J, Gaillardet J (2014) How accurate are rivers as gauges of chemical denudation of the Earth surface? Geology 42:171-174

Bouchez J, Gaillardet J, Lupker M et al (2012) Floodplains of large rivers: weathering reactors or simple silos? Chem Geol 332-333:166-184

Bouchez J, Gaillardet J, Von Blanckenburg F (2014) Weathering intensity in lowland river basins: from the Andes to the Amazon mouth. Procedia Earth Planet Sci. pp 280-286

Bowes MJ, House WA, Hodgkinson RA, Leach DV (2005) Phosphorusdischarge hysteresis during storm events along a river catchment: the River Swale, UK. Water Res 39:751-762

Boy J, Valarezo C, Wilcke W (2008) Water flow paths in soil control element exports in an Andean tropical montane forest. Eur J Soil Sci 59:1209-1227

Bustillo V, Victoria RL, Sousa de Moura JM et al (2010) Biogeochemistry of the Amazonian floodplains: insights from six end-member mixing models. Earth Interact 14:1-83

Bustillo V, Victoria RL, Sousa de Moura JM et al (2011) Factors driving the biogeochemical budget of the Amazon River and its statistical modelling. Compt Rendus Geosci 343:261-277

Callède J, Cochonneau G, Ronchail J et al (2010) Les apports en eau de l'Amazone à l'océan Atlantique. Rev Sci Eau 23 
Calmels D, Gaillardet J, Brenot A, France-Lanord C (2007) Sustained sulfide oxidation by physical erosion processes in the Mackenzie River basin: climatic perspectives. Geology 35:1003-1006

Carretier S, Godderis Y, Delannoy T, Rouby D (2014) Mean bedrock-tosaprolite conversion and erosion rates during mountain growth and decline. Geomorphology 209:39-52

Chaudhuri S, Clauer N, Semhi K (2007) Plant decay as a major control of river dissolved potassium: a first estimate. Chem Geol 243:178-190

Chen J, Wang F, Xia X, Zhang L (2002) Major element chemistry of the Changjiang (Yangtze River). Chem Geol 187:231-255

Clow DW, Mast MA (2010) Mechanisms for chemostatic behavior in catchments: implications for $\mathrm{CO} 2$ consumption by mineral weathering. Chem Geol 269:40-51

Cochonneau G, Sondag F, Jean-Loup G, et al. (2006) L'Observatoire de Recherche en Environnement, ORE HYBAM sur les grands fleuves amazoniens $=$ The Environmental Observation and Research project, ORE HYBAM, and the rivers of the Amazon basin. The Fifth FRIEND World Conference held Climate: Variability and ChangeHydrological Impacts 308

Coynel A, Seyler P, Etcheber H et al (2005) Spatial and seasonal dynamics of total suspended sediment and organic carbon species in the Congo River. Glob Biogeochem Cycles 19, GB4019

Creed IF, Mcknight DM, Pellerin BA et al (2015) The river as a chemostat: fresh perspectives on dissolved organic matter flowing down the river continuum. Can J Fish Aquat Sci 72:1272-1285. doi: 10.1139/cjfas-2014-0400

Cullmann J, Junk WJ, Weber G, Schmitz GH (2006) The impact of seepage influx on cation content of a Central Amazonian floodplain lake. J Hydrol 328:297-305

Dai A, Trenberth KE (2002) Estimates of freshwater discharge from continents: latitudinal and seasonal variations. J Hydrometeorol 3: 660-687

Devol AH, Forsberg BR, Richey JE, Pimentel TP (1995) Seasonal variation in chemical distributions in the Amazon (Solimões) river: a multiyear time series. Glob Biogeochem Cycles 9:307-328

Dijkshoorn K, Huting J, Tempel P (2005) Update of the 1:5 million Soil and Terrain Database for Latin America and the Caribbean (SOTERLAC)

Dunne T, Mertes LAK, Meade RH et al (1998) Exchanges of sediment between the flood plain and channel of the Amazon River in Brazil. Geol Soc Am Bull 110:450-467

Dupré B, Dessert C, Oliva P et al (2003) Rivers, chemical weathering and Earth's climate. C R Geosci 335:1141-1160

Edmond JM, Palmer MR, Measures CI et al (1996) Fluvial geochemistry of the eastern slope of the northeastern Andes and its foredeep in the drainage of the Orinoco in Colombia and Venezuela. Geochim Cosmochim Acta 60:2949-2974

Edokpa DA, Evans MG, Rothwell JJ (2015) High fluvial export of dissolved organic nitrogen from a peatland catchment with elevated inorganic nitrogen deposition. Sci Total Environ 532:711-722

Eiriksdottir ES, Gislason SR, Oelkers EH (2013) Does temperature or runoff control the feedback between chemical denudation and climate? Insights from NE Iceland. Geochim Cosmochim Acta 107:65-81

Espinoza VJC, Guyot JL, Ronchail J et al (2009a) Contrasting regional discharge evolution in the Amazon Basin. J Hydrol 375:297-311

Espinoza VJ-C, Ronchail J, Guyot J-L et al (2009b) Spatio-temporal rainfall variability in the Amazon basin countries (Brazil, Peru, Bolivia, and Ecuador). Int J Climatol 29:1574-1594

Espinoza VR, Martinez J-M, Le Texier M et al (2013) A study of sediment transport in the Madeira River, Brazil, using MODIS remotesensing images. J S Am Earth Sci 44:44-54

Evans C, Davies TD (1998) Causes of concentration/discharge hysteresis and its potential as a tool for analysis of episode hydrochemistry. Water Resour Res 34:129-137
Filizola N, Guyot JL (2009) Suspended sediment yields in the Amazon basin: an assessment using the Brazilian national data set. Hydrol Process 23:3207-3215

Filizola N, Guyot J-L, Wittmann H, et al. (2011) The significance of suspended sediment transport determination on the Amazonian hydrological scenario. In: Andrew J. Manning Ed. Sediment transport in aquatic environments

Furch K, Junk WJ, Klinge H (1982) Unusual chemistry of natural waters from the Amazon Region. Acta Cient Venez 33:269-273

Gaillardet J, Dupré B, Allègre C-J, Négrel P (1997) Chemical and physical denudation in the Amazon River Basin. Chem Geol 142:141-173

Gaillardet J, Dupre B, Allègre CJ (1999) Geochemistry of large river suspended sediments: silicate weathering or recycling tracer? Geochim Cosmochim Acta 63:4037-4051

Galy A, France-Lanord C (1999) Weathering processes in the GangesBrahmaputra basin and the riverine alkalinity budget. Chem Geol 159:31-60

Garreaud RD, Vuille M, Compagnucci R, Marengo J (2009) Present-day South American climate. Palaeogeogr Palaeoclimatol Palaeoecol 281:180-195

Getirana ACV, Bonnet MP, Rotunno Filho OC et al (2010) Hydrological modelling and water balance of the Negro River basin: evaluation based on in situ and spatial altimetry data. Hydrol Process 24:3219 3236

Gibbs RJ (1967a) Amazon rivers: environmental factors that control its dissolved and suspended load. Science 156:1734-1737

Gibbs RJ (1967b) The geochemistry of the Amazon River system: part I. The factors that control the salinity and the composition and concentration of the suspended solids. Geol Soc Am Bull 78:1203-1232

Gibbs RJ (1972) Water chemistry of the Amazon River. Geochim Cosmochim Acta 36:1061-1066

Giorgi F, Diffenbaugh N (2008) Developing regional climate change scenarios for use in assessment of effects on human health and disease. Clim Res 36:141-151

Gislason SR, Oelkers EH, Eiriksdottir ES et al (2009) Direct evidence of the feedback between climate and weathering. Earth Planet Sci Lett 277:213-222

Godderis Y, François LM, Probst A et al (2006) Modelling weathering processes at the catchment scale: the WITCH numerical. Geochim Cosmochim Acta 70:1128-1147

Godsey SE, Kirchner JW, Clow DW (2009) Concentration-discharge relationships reflect chemostatic characteristics of US catchments. Hydrol Process 23:1844-1864

Goudie AS, Viles HA (2012) Weathering and the global carbon cycle: geomorphological perspectives. Earth Sci Rev 113:59-71

GRDC (2014) Global freshwater fluxes into the world oceans/online provided by Global Runoff Data Centre. ed. Koblenz: Federal Institute of Hydrology (BfG), 2014

Guan K, Thompson SE, Harman CJ et al (2011) Spatiotemporal scaling of hydrological and agrochemical export dynamics in a tile-drained midwestern watershed. Water Resour Res 47:W00J02

Guimberteau M, Drapeau G, Ronchail J et al (2012) Discharge simulation in the sub-basins of the Amazon using ORCHIDEE forced by new datasets. Hydrol Earth Syst Sci 16:911-935

Guyot J-L (1993) Hydrogéochimie des fleuves de l'Amazonie Bolivienne. ORSTOM, Paris

Guyot JL, Jouanneau JM, Quintanilla J, Wasson JG (1993) Les flux de matières dissoutes et particulaires exportés des Andes par le Rio Béni (Amazonie bolivienne), en période de crue. Geodin Acta 6: 233-241

Guyot JL, Filizola NP, Quintanilla J, Cortes J (1996) Dissolved solids and suspended sediment yields in the Rio Madeira basin, from the Bolivian Andes to the Amazon. In: IAHS (Ed.), IAHS, pp. 55-63 
Guyot JL, Quintanilla J, Martinez J, Calle H (1998) Regional characteristics of the hydrochemistry in the humid tropics of Bolivian Amazonia. In: Hydrology in the humid tropic environment. Johnson A.I. et Fernandez Jauregui C. IAHS Publ., pp. 447-457

Guyot JL, Filizola N, Laraque A (2005) The suspended sediment flux of the River Amazon at Obidos, Brazil, 1995-2003. In: Walling DE, Horowitz AJ (eds) Paper read at 7th IAHS Scientific AssemblySediment Budgets. Foz do Iguaco (Brazil), pp 347-354

Herndon EM, Dere AL, Sullivan PL et al (2015) Biotic controls on solute distribution and transport in headwater catchments. Hydrol Earth Syst Sci 12:213-243

House WA, Warwick MS (1998) Hysteresis of solute concentration/ discharge relationship in rivers during storms. Water Resour Res 32:2279-2290

Insel N, Poulsen CJ, Ehlers TA (2009) Influence of the Andes Mountains on South American moisture transport, convection, and precipitation. Clim Dyn. doi:10.1007/s00382-009-0637-1

Jansson MB (2002) Determining sediment source areas in a tropical river basin, Costa Rica. CATENA 47:63-84

Jawitz JW, Mitchell J (2011) Temporal inequality in catchment discharge and solute export. Water Resources Research 47:W00J14

Junk W, Piedade M (1997) Plant life in the floodplain with special reference to herbaceous plants. Springer, Heidelberg

Kirchner JW (2003) A double paradox in catchment hydrology and geochemistry. Hydrol Process 17:871-874

Konhauser KO, Fyfe WS, Kronberg BI (1994) Multi-element chemistry of some Amazonian waters and soils. Chem Geol 111:155-175

Laraque A, Bernal C, Bourrel L et al (2009) Sediment budget of the Napo River, Amazon basin, Ecuador and Peru. Hydrol Process 23:35093524

Laraque A, Moquet JS, Alkattan R et al (2013) Seasonal variability of total dissolved fluxes and origin of major dissolved elements within a large tropical river: the Orinoco, Venezuela. J S Am Earth Sci 44: 4-17

Lasaga AC, Berner RA (1998) Fundamental aspects of quantitative models for geochemical cycles. Chem Geol 145:161-175

Lavado Casimiro WS, Labat D, Ronchail J, et al. (2012) Trends in rainfall and temperature in the Peruvian Amazon-Andes basin over the last 40 years (1965-2007). Hydrological Processes On line

Leon JG, Pedrozo FL (2015) Lithological and hydrological controls on water composition: evaporite dissolution and glacial weathering in the south central Andes of Argentina $\left(33^{\circ}-34^{\circ} \mathrm{S}\right)$. Hydrol Process 29:1156-1172

Li Z, Gao W, Zhang M, Gao W (2012) Variations in suspended and dissolved matter fluxes from glacial and non-glacial catchments during a melt season at Urumqi River, eastern Tianshan, central Asia. Catena 95:42-49

Li DD, Jacobson AD, McInerney DJ (2014) A reactive transport model for examining tectonic and climatic controls on chemical weathering and atmospheric $\mathrm{CO} 2$ consumption in granitic regolith. Chem Geol 365:30-42

Lucas Y (2001) The role of plants in controlling rates and products of weathering: importance of biological pumping. Annu Rev Earth Planet Sci 29:135-163

Lupker M, France-Lanord C, Lavé J et al (2012) Predominant floodplain over mountain weathering of Himalayan sediments (Ganga Basin). Geochim Cosmochim Acta 84:410-432

Magrin G, Marengo J, Boulanger J-P, et al. (2014) Chapter 27. Central and South America. Climate change 2014: impacts, adaptation, and vulnerability. Working Group II of the IPCC. Volume II: Regional Aspects Contribution of Working Group II to the Fifth Assessment Report of the Intergovernmental Panel on Climate Change

Maher K (2010) The dependence of chemical weathering rates on fluid residence time. Earth Planet Sci Lett 294:101-110
Maher K (2011) The role of fluid residence time and topographic scales in determining chemical fluxes from landscapes. Earth Planet Sci Lett 312:48-58

Maher K, Druhan J (2014) Relationships between the transit time of water and the fluxes of weathered elements through the critical zone. Earth Planet Sci 10:16-22

Maher K, Chamberlain CP (2014) Hydrologic regulation of chemical weathering and the geologic carbon cycle. Science 343:1502-1504

Marengo J (2004) Interdecadal variability and trends of rainfall across the Amazon basin. Theoretical and applied climatology 79-96

Marengo JA, Chou SC, Kay G et al (2011) Development of regional future climate change scenarios in South America using the Eta CPTEC/HadCM3 climate change projections: climatology and regional analyses for the Amazon, São Francisco and the Paraná River Basins. Clim Dyn 38:1829-1848

Marengo J, Liebmann B, Grimm AM et al (2012) Review-recent developments on the South American monsoon system. Int J Climatol 32:1-21

Markewitz D, Davidson EA, Figueiredo RDO et al (2001) Control of cation concentrations in stream waters by surface soil processes in an Amazonian watershed. Nature 410:802-805

Markewitz D, Resende J, Parron L et al (2006) Dissolved rainfall inputs and streamwater outputs in an undisturbed watershed on highly weathered soils in the Brazilian cerrado. Hydrol Process 20:26152639

Martinez J-M, Guyot J-L, Filizola N, Sondag F (2009) Increase in suspended sediment discharge of the Amazon River assessed by monitoring network and satellite data. Catena 79:257-264

McClain ME, Naiman RJ (2008) Andean influences on the biogeochemistry and ecology of the Amazon River. BioScience 58:325-338

Meade RH (1994) Suspended sediments of the modern Amazon and Orinoco Rivers. In: Quaternary of South America (M. Iriondo, Ed.). Quaternary International. 21:29-39

Meade RH, Dunne T, Richey JE et al (1985) Storage and remobilization of suspended sediment in the lower Amazon River of Brazil. Science 228:488-490

Meade RH, Rayol JM, Conceiteo SC, Natividade JRG (1991) Backwater effects in the Amazon River basin of Brazil. Environ Geol Water Sci $18: 105-114$

Meybeck M (2003) Global occurence of major elements in rivers. In: HD Holland, K.K. Turekian (eds) Treatise on geochemistry. Volume 5: surface and ground water, weathering and soils (J. Drever ed), Pergamon: 207-224

Meybeck M, Pasco A, Ragu A (1996) Evaluation des flux polluants dans les eaux superficielles Etude inter-Agence de l'eau

Milliman JD, Farnsworth KL (2011) River discharge to the coastal ocean - a global synthesis. Cambridge University Press, Cambridge

Mills B, Lenton TM, Watson AJ (2014) Proterozoic oxygen rise linked to shifting balance between seafloor and terrestrial weathering. Proc Natl Acad Sci 111:9073-9078

Moatar F, Birgand F, Meybeck M et al (2009) Incertitudes sur les métriques de qualité des cours d'eau (médianes et quantiles de concentrations, flux, cas des nutriments) évaluées a partir de suivis discrets. La Houille Blanche 3:68-76

Moon S, Chamberlain CP, Hilley GE (2014) New estimates of silicate weathering rates and their uncertainties in global rivers. Geochim Cosmochim Acta 134:257-274

Moquet J-S, Crave A, Viers J et al (2011) Chemical weathering and atmospheric/soil $\mathrm{CO} 2$ uptake in the Andean and Foreland Amazon basins. Chem Geol 287:1-26

Moquet JS, Maurice L, Crave A et al (2014a) Cl and $\mathrm{Na}$ fluxes in an Andean foreland basin of the Peruvian Amazon: an anthropogenic impact evidence. Aquat Geochem 20:613-637

Moquet JS, Viers J, Crave A, et al. (2014a) Comparison between silicate weathering and physical erosion rates in Andean basins of Amazon River. Procedia earth \& planetary science. Paris France, pp 275-279 
Moreira-Turcq P, Seyler P, Guyot JL, Etcheber H (2003) Exportation of organic carbon from the Amazon River and its main tributaries. Hydrol Process 17:1329-1344

Mortatti J, Probst J-L (2003) Silicate rock weathering and atmospheric/ soil $\mathrm{CO} 2$ uptake in the Amazon basin estimated from river water geochemistry: seasonal and spatial variations. Chem Geol 197:177-196

Mortatti J, Moares JM, Victoria RL, Martinelli LA (1997) Hydrograph separation of the Amazon River: a methodological study. Aquat Geochem 3:117-128

Négrel P, Roy S, Petelet-Giraud E et al (2007) Long-term fluxes of dissolved and suspended matter in the Ebro River Basin (Spain). J Hydrol 342:249-260

Nkounkou RR, Probst JL (1987) Hydrology and geochemistry of the Congo river system. Mitt Geol-Palaont Inst Univ Hamburg, SCOPErUNEP 64:483-508

Nogués Paegle J, Mechoso CR, Fu R et al (2002) Progress in Pan American CLIVAR research: understanding the South American monsoon. Meteorologica 27:1-30

O'Connor EM, Mc Connell C, Lembcke D, Winter JG (2011) Estimation of total phosphorus loads for a large, flashy river of a highly developed watershed - seasonal and hysteresis effects. J Great Lakes Res 37:26-35

Ollivier P, Radakovitch O, Hamelin B (2006) Unusual variations of dissolved $\mathrm{As}, \mathrm{Sb}$ and $\mathrm{Ni}$ in the Rhône River during flood events. J Geochem Explor 88:394-398

Oltman RE (1967) Reconnaissance investigations of the discharge and water quality of the Amazon. Bel,m, pp 163-185

Oltman RE, Sternberg HO, Ames FC, Davis LC (1964) Amazon River investigations reconnaissance measurements of July 1963. Geol Surv Circ 486:1-15

Paiva RCD, Buarque DC, Collischonn W et al (2013) Large-scale hydrologic and hydrodynamic modeling of the Amazon River basin. Water Resour Res 49:1226-1243

Pepin E, Guyot JL, Armijos E et al (2013) Climatic control on eastern Andean denudation rates (Central Cordillera from Ecuador to Bolivia). J S Am Earth Sci 44:85-93

Raymo ME, Ruddiman WF (1992) Tectonic forcing of late Cenozoic mountain building on ocean geochemical cycles. Geology 359: $117-122$

Richey JE, Meade RH, Salati E et al (1986) Water discharge and suspended sediment concentrations in the Amazon River. Water Resour Res 22:756-764

Rios-Villamizar EA, Piedade MTF, da Costa JG et al (2014) Chemistry of different Amazonian water types for river classification: a preliminary review. WIT Trans Ecol Environ. doi:10.2495/13WS0021

Roche MA, Fernandez Jauregui C (1988) Water resources, salinity and salt yields of the rivers of the Bolivian Amazon. J Hydrol 101:305-331

Roche MA, Aliaga A, Campos J et al (1990) Hétérogénéité des précipitations sur la cordillère des Andes boliviennes. In: MA LHE (ed) Hydrology in mountainous regions. I. Hydrological measurements, the water cycle. IAHS, Lausanne (Suisse), pp 381-388

Roddaz M, Viers J, Brusset S et al (2005) Sediment provenances and drainage evolution of the Neogene Amazonian foreland basin. Earth Planet Sci Lett 239:57-78

Rose S (2003) Comparative solute-discharge hysteresis analysis for an urbanized and a "control basin" in the Georgia (USA) Piedmont. J Hydrol 284:45-56

Roy S, Gaillardet J, Allègre CJ (1999) Geochemistry of dissolved and suspended loads of the Seine River, France: anthropogenic impact, carbonate and silicate weathering. Geochim Cosmochim Acta 63: $1277-1292$

Sanchez LSH, Horbe A, Moquet JS et al (2015) Variação espaço-temporal do material inorgânico dissolvido na bacia Amazônica. Acta Amazon 45

Santini W, Martinez JM, Espinoza VR et al (2014) Sediment budget in the drainage basin of the Ucayali River, an Andean tributary of the Amazon. IAHS Publ, Louisiana, pp 320-325

Sioli H (1964) General features of the limnology of Amazonia. VerhInternatVereinLimnol 15:1053-1058

Sondag F, Guyot JL, Moquet JS et al (2010) Suspended sediment and dissolved load budgets of two Amazonian rivers from French Guiana: Maroni and Oyapock rivers. Hydrol Process 24:1433-1445

Stallard RF (1985) River chemistry, geology, geomorphology, and soils in the Amazon and Orinoco Basins. In: JI Drever (Ed). The chemistry of weathering. D Reidel Publishing Company 293-316

Stallard RF, Edmond JM (1983) Geochemistry of the Amazon. 2. The influence of geology and weathering environment on the dissolved load. J Geophys Res 88:9671-9688

Stallard RF, Edmond JM (1987) Geochemistry of the Amazon. 3. Weathering chemistry and limits to dissolved inputs. J Geophys Res 92:8293-8302

Tardy Y, Bustillo V, Roquin C et al (2005) The Amazon. Bio-geochemistry applied to river basin management: part I. Hydro-climatology, hydrograph separation, mass transfer balances, stable isotopes, and modelling. Appl Geochem 20:1746-1829

Torres MA, West AJ, Clark KE (2015) Geomorphic regime modulates hydrologic control of chemical weathering in the Andes-Amazon. Geochim Cosmochim Acta 166:105-128

Townsend-Small A, McClain ME, Hall B et al (2008) Suspended sediments and organic matter in mountain headwaters of the Amazon River: results from a 1-year time series study in the central Peruvian Andes. Geochim Cosmochim Acta 72:732-740

Vauchel P (2005) HYDRACCESS: software for management and processing of hydro-meteorological data. www.mpl.ird.fr/hybam/outils/ hydraccess

Vera C, Higgins W, Amador J et al (2006) Toward a unified view of the American monsoon systems. Am Meteorol Soc 19:4977-5000

Viers J, Barroux G, Pinelli M et al (2005) The influence of the Amazonian floodplain ecosystems on the trace element dynamics of the Amazon River mainstem (Brazil). Sci Total Environ 339:219-232

Von Blanckenburg F, Bouchez J, Ibarra DE, Maher K (2015) Stable runoff and weathering fluxes into the oceans over Quaternary climate cycles. Nat Geosci 8:538-542. doi:10.1038/NGEO2452

Walling DE, Webb BW (1982) Sediment availability and the prediction of storm-period sediment yields. Int Assoc Hydrol Sci Publ 137:327337

Walling DE, Webb BW (1983) Patterns of sediment yield. In: Gregory KJ (ed) Background to palaeohydrology. Wiley, Chichester, pp 69-100

Wilcke W, Yasin S, Valarezo C, Zech W (2001) Change in water quality during the passage through a tropical montane rain forest in Ecuador. Biogeochemistry 55:45-72

Wilcke W, Valladarez H, Stoyan R et al (2003) Soil properties on a chronosequence of landslides in montane rain forest, Ecuador. Catena 53:79-95

Wood PA (1977) Controls of variation in suspended sediment concentration in the river Rother, West Sussex, England. Sedimentology 24: 437-445

Yuan F, Mivamoto S, Anand S (2007) Changes in major element hydrochemistry of the Pecos River in the American Southwest since 1935. Appl Geochem 22:1798-1813. doi:10.1016/j.apgeochem. 2007.03.036 